\title{
The impact of soil uptake on the global distribution of molecular hydrogen: chemical transport model simulation
}

\author{
H. Yashiro ${ }^{1}$, K. Sudo ${ }^{1,2}$, S. Yonemura ${ }^{3}$, and M. Takigawa ${ }^{1}$ \\ ${ }^{1}$ Research Institute for Global Change, Japan Agency for Marine-Earth Science and Technology, Yokohama, Japan \\ ${ }^{2}$ Graduate School of Environmental Studies, Nagoya University, Nagoya, Japan \\ ${ }^{3}$ National Institute for Agro-Environmental Sciences, Tsukuba, Japan \\ Received: 13 December 2010 - Published in Atmos. Chem. Phys. Discuss.: 4 February 2011 \\ Revised: 26 June 2011 - Accepted: 30 June 2011 - Published: 13 July 2011
}

\begin{abstract}
The global tropospheric distribution of molecular hydrogen $\left(\mathrm{H}_{2}\right)$ and its uptake by the soil are simulated using a model called CHemical AGCM (atmospheric general circulation model) for the Study of the Environment and Radiative forcing (CHASER), which incorporates a twolayered soil diffusion/uptake process component. The simulated distribution of deposition velocity over land is influenced by regional climate, and has a global average of $3.3 \times 10^{-2} \mathrm{~cm} \mathrm{~s}^{-1}$. In the region north of $30^{\circ} \mathrm{N}$, the amount of soil uptake shows a large seasonal variation corresponding to change in biological activity due to soil temperature and change in diffusion suppression by snow cover. In the temperate and humid regions in the mid- to low- latitudes, the uptake is mostly influenced by the soil air ratio, which controls the gas diffusivity in the soil. In the semi-arid regions, water stress and high temperatures contribute to the reduction of biological activity, as well as to the seasonal variation in the deposition velocity. A comparison with the observations shows that the model reproduces both the distribution and seasonal variation of $\mathrm{H}_{2}$ relatively well. The global burden and tropospheric lifetime of $\mathrm{H}_{2}$ are $150 \mathrm{Tg}$ and $2.0 \mathrm{yr}$, respectively. The seasonal variation in $\mathrm{H}_{2}$ mixing ratios at the northern high latitudes is mainly controlled by a large seasonal change in the soil uptake. In the Southern Hemisphere, seasonal change in net chemical production and inter-hemispheric transport are the dominant causes of the seasonal cycle, while large biomass burning contributes significantly to the seasonal variation in the tropics and subtropics. Both observations and the model show large interannual variations, especially for the period 1997-1998, as-
\end{abstract}

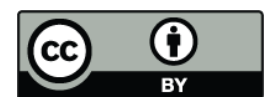

Correspondence to: $\mathrm{H}$. Yashiro (h.yashiro@jamstec.go.jp) sociated with large biomass burning in the tropics and at Northern Hemisphere high latitudes. The soil uptake shows relatively small inter-annual variability compared with the biomass burning signal. Given that the thickness of biologically inactive layer plays an important role in the soil uptake of $\mathrm{H}_{2}$, its value in the model is chosen to achieve agreement with the observed $\mathrm{H}_{2}$ trends. Uncertainty of the estimated soil uptake flux in the semi-arid region is still large, reflecting the discrepancy in the observed and modeled seasonal variations.

\section{Introduction}

In the troposphere, molecular hydrogen $\left(\mathrm{H}_{2}\right)$ has an average mixing ratio of $\sim 530 \mathrm{ppb}$ (parts per billion), the second highest after methane $\left(\mathrm{CH}_{4}, \sim 1750 \mathrm{ppb}\right)$ among the reactive tracers. Its lifetime $(\sim 2 \mathrm{yr})$ is shorter than $\mathrm{CH}_{4}(9-11 \mathrm{yr})$ and longer than carbon monoxide ( $\mathrm{CO}, \sim 3$ months) (see Ehhalt and Rohrer (2009) and references therein). Although many of the anthropogenic sources are widely distributed over the land surface in the Northern Hemisphere, ground and airborne observations indicate the presence of lowest $\mathrm{H}_{2}$ mixing ratios in the mid- and high- latitude regions near the soil surface in the Northern Hemisphere (Novelli et al., 1999). $\mathrm{H}_{2}$ mixing ratios increase towards the tropics, becoming relatively uniform with latitude in the Southern Hemisphere. This distribution differs from those of other trace gases like $\mathrm{CO}_{2}, \mathrm{CH}_{4}$ and chlorofluorocarbons. It is also interesting to note that, although the tropospheric sources of $\mathrm{CO}$ and $\mathrm{H}_{2}$ are similar, their latitudinal distributions and seasonal variations are different. One reason for this is that one of the major factors contributing to the observed spatio-temporal distribution

Published by Copernicus Publications on behalf of the European Geosciences Union. 
of $\mathrm{H}_{2}$ is the soil uptake, which makes up about $75-82 \%$ of the sink. $\mathrm{H}_{2}$ is produced from formaldehyde ( $\mathrm{HCHO}$ ) in the atmosphere through a chemical reaction process that begins with oxidization of $\mathrm{CH}_{4}$ or non-methane volatile organic compounds (NMVOCs). Moreover, $\mathrm{H}_{2}$ is oxidized by a reaction with $\mathrm{OH} . \mathrm{H}_{2}$ is thus continuously generated in the troposphere, and is removed by soil or chemical reaction, or is exchanged with the stratosphere.

The $\mathrm{H}_{2}$ emissions from fossil fuel consumption and industrial activities have been increasing since the beginning of the industrial era. It is likely that when humans shift to the "hydrogen-economy" society, with hydrogen as a secondary energy source and/or energy carrier, a large amount of $\mathrm{H}_{2}$ could leak into the atmosphere. Some studies have shown that an increasing $\mathrm{H}_{2}$ concentration reduces the atmospheric oxidization capacity, and influences the temperature and ozone loss in the stratosphere through the production of water vapor (Prather et al., 2003; Schultz et al., 2003; Tromp et al., 2003; Warwick et al., 2004).

Although the soil uptake of $\mathrm{H}_{2}$ is very important in the global $\mathrm{H}_{2}$ cycle, we have a limited understanding of the uptake process, resulting in large uncertainties associated with the estimation of its global distribution and seasonal variation. Absorption of $\mathrm{H}_{2}$ in the soil is mainly performed by several types of extracellular enzymes (hydrogenase), which are believed to exist universally in the soil (Conrad et al., 1983). Previous studies have shown that most of this absorption is accomplished within several centimeters of soil below the surface (Yonemura et al., 1999). Soil temperature and moisture control much of the biological activity, while snow, litter function and heated soil layer can act as a diffusion barrier near the surface (Yonemura et al., 1999, 2000a, b; Smith-Downey et al., 2006b, 2008; Schmitt et al., 2009).

Global simulations of the $\mathrm{H}_{2}$ concentration and its isotope composition have been conducted by other investigators. Hauglustaine and Ehhalt (2002) used a chemical transport model to show good agreement between the observed and simulated $\mathrm{H}_{2}$ mixing ratio in the Southern Hemisphere and the tropics, but reported an overestimation of the seasonal maximum in the Northern Hemisphere. This may have resulted from their estimation of the soil uptake flux derived from net primary productivity (NPP). Sanderson et al. (2003) used a Lagrangian model to simulate the spatial and temporal variation of deposition velocity, which depends on the vegetation type, snow cover, and soil moisture. Their model reproduced reasonably well the observed seasonal variations at various stations. The same applies to a recent model study by Pieterse et al. (2011), who used a deposition scheme based on Sanderson et al. (2003). Price et al. (2007) also used deposition velocity as a function of snow cover and soil temperature, to reproduce relatively well the latitudinal and seasonal variations of $\mathrm{H}_{2}$ concentration and its isotope ratio. They obtained an annual soil uptake of 50-60 Tg. The deposition velocities were constrained by the observations, and the soil uptake was empirically based, without explicitly taking into consideration the actual soil uptake process. There have also been other studies that have used the top down approach, resulting in a larger estimated soil uptake (Rhee et al., 2006; Xiao et al., 2007).

In this study, we used a global chemistry transport model combined with a land process model that included explicitly the soil uptake processes, to calculate the surface deposition flux and the concentration of $\mathrm{H}_{2}$, and discuss the spatial and temporal variations and the global budget of $\mathrm{H}_{2}$ in the troposphere.

\section{Model description}

\subsection{Global chemical transport model and land process model}

CHASER is a three-dimensional atmospheric chemical climate/transport model, which has been developed in the framework of an AGCM developed jointly by the Center for Climate System Research (CCSR), the National Institute for Environment Studies (NIES), and the Frontier Research Center for Global Change (FRCGC). The details of the model are described in Sudo et al. (2002a, 2007), and an evaluation of the model performance showed good agreement between model simulations and observations for $\mathrm{O}_{3}$ and its precursor species (Sudo et al., 2002b). The model performance was also evaluated in the framework of the 4th Assessment Report of the Intergovernmental Panel on Climate Change (IPCC) (e.g., Shindell et al. 2005; van Noije et al., 2006). The CHASER model adopted in this study includes several improvements; the model is based on the new version of CCSR/NIES/FRCGC AGCM (Watanabe et al., 2008) developed as the atmospheric component of MIROC (Model for Interdisciplinary Research on Climate), (K-1 developers, 2004). In the new version of AGCM, the $\sigma$ vertical coordinate system has been replaced by a hybrid $\sigma$ pressure vertical coordinate system. The updated radiation scheme by Sekiguchi and Nakajima (2008) has been adopted. A non-local turbulence closure scheme based on Holtslag and Boville (1993) was applied to the sub-grid transport of trace gases due to turbulent mixing, in conjunction with the Mellor-Yamada level 2 scheme. For this study, a horizontal resolution of $\mathrm{T} 42\left(2.8^{\circ} \times 2.8^{\circ}\right)$ was adopted, with 32 vertical layers from the surface to about $40 \mathrm{~km}$ altitude $(\sim 1 \mathrm{~km}$ vertical resolution in the upper troposphere and lower stratosphere). In order to reduce model bias and to obtain realistic meteorological fields for the period 1989-2006, the horizontal wind and temperature fields were nudged to the JRA-25 reanalysis data (Onogi et al., 2005). The relaxation time was optimized and set to 1 day for the horizontal wind and 5 days for temperature, in accordance with Miyazaki et al. (2005).

The model considers a detailed online simulation of the tropospheric chemistry involving the $\mathrm{O}_{3}-\mathrm{HO}_{\mathrm{x}}-\mathrm{NO}_{\mathrm{x}}-\mathrm{CH}_{4}-\mathrm{CO}$ system and the oxidation of NMVOCs with a time-step 
of $10 \mathrm{~min}$, and includes detailed dry and wet deposition schemes. The oxidation of $\mathrm{CH}_{4}$ and NMVOCs constitutes a large source of $\mathrm{H}_{2}$ in the model, with photolysis of $\mathrm{HCHO}$ leading to the formation of $\mathrm{H}_{2}$. Details of the chemical reaction system are described in Sudo et al. (2002a), to which we added the reaction of $\mathrm{H}_{2}$ with the $\mathrm{OH}$ radical,

$\mathrm{H}_{2}+\mathrm{OH} \rightarrow \mathrm{H}_{2} \mathrm{O}+\mathrm{H}$

with the rate constant of $k_{\mathrm{H}_{2}+\mathrm{OH}}(T)=7.7 \times 10^{-12} \times$ $\exp (-2100 / T) \mathrm{cm}^{3}$ molecule ${ }^{-1} \mathrm{~s}^{-1}$ (Atkinson et al., 2004).

In this study, the surface emissions of $\mathrm{CO}, \mathrm{NO}_{\mathrm{x}}, \mathrm{CH}_{4}$, NMVOCs, $\mathrm{SO}_{2}$ and dimethyl sulfide are included in CHASER. Other modifications made to the model for the this study are as follows: Anthropogenic emissions of $\mathrm{CO}, \mathrm{NO}_{\mathrm{x}}$, $\mathrm{CH}_{4}$ and $\mathrm{SO}_{2}$ are based on EDGAR v3.2 1990, 1995 and "Fast-Track" 2000 (Olivier et al., 2005). The source strength at each model grid from 1990 to 2005 is obtained by linearly interpolating and extrapolating the 1990, 1995, and 2000 values. After 2005, the same source strength that is used for 2005 is applied. For $\mathrm{CO}$ and $\mathrm{NO}_{\mathrm{x}}$ emissions from China, we switch from the EDGAR inventory to REAS v1.1 (Ohara et al., 2007) for the period 1989 to 2006 . For $\mathrm{CO}, \mathrm{NO}_{\mathrm{x}}$, $\mathrm{CH}_{4}$, NMVOCs and $\mathrm{SO}_{2}$ emissions from biomass burning, we adopt GFED v2.1 (van der Werf et al., 2006). Monthly averaged values of these emissions are assigned for the period 1997-2000, while 8-day average values are used after 2001. The values before 1997 for each selected source region are assumed to be constant, at a median value for the 1997-2007 monthly CO emissions data. For biogenic emissions of NMVOCs, monthly emission data by Guenther et al. (1995), which are obtained from the Global Emissions Inventory Activity (GEIA) database, are used with 420, 106 and $70 \mathrm{TgC} \mathrm{yr}^{-1}$ for $\mathrm{C}_{5} \mathrm{H}_{8}, \mathrm{C}_{10} \mathrm{H}_{16}$ and $\mathrm{CH}_{3} \mathrm{OH}$, respectively. For other $\mathrm{CO}$ emission, monthly distributions of biogenic and oceanic CO emission given by Muller et al. (1992) are used. The global source strength of biogenic $\mathrm{CO}$ emission is set to $160 \mathrm{Tg} \mathrm{yr}^{-1}$ and that of the oceanic emissions scaled to $10 \mathrm{Tg} \mathrm{yr}^{-1}$. Emissions of NMVOCs from the ocean are adopted with the same distribution as the oceanic $\mathrm{CO}$ emissions.

There are a few global emission inventories of $\mathrm{H}_{2}$. For anthropogenic emissions, the surface source distribution of $\mathrm{H}_{2}$ in this study is determined by applying the $\mathrm{H}_{2} / \mathrm{CO}$ emission ratio to the emission inventory of $\mathrm{CO}$. Ehhalt and Rohrer (2009) summarized the observational results and estimated an $\mathrm{H}_{2} / \mathrm{CO}$ ratio of $0.5 \pm 0.1 \mathrm{~mol} \mathrm{~mol}^{-1}$ and $0.2 \pm 0.15 \mathrm{~mol} \mathrm{~mol}^{-1}$ for automobiles and industrial sector, respectively. We apply these emission ratios and $0.32 \mathrm{~mol} \mathrm{~mol}^{-1}$ for biofuel combustion (Andreae and Merlet, 2001) to the EDGAR and REAS inventory. GFED v2.1 is used for the $\mathrm{H}_{2}$ emissions from biomass burning. Large uncertainties still remain in the $\mathrm{H}_{2}$ emission estimates for the land and ocean as a by-product of biogenic nitrogen fixation. Based on the detailed discussion in Ehhalt and Rohrer
(2009), we employ values of 3 and $6 \mathrm{Tg} \mathrm{yr}^{-1}$ for land and ocean emissions, respectively. The spatial and temporal distributions of these emissions are estimated by using the distribution of biogenic and oceanic $\mathrm{CO}$ emissions as proxies of biological activity. It is important to note that the enzyme involved in the $\mathrm{H}_{2}$ production (nitrogenase) responsible for the soil biogenic emission of $\mathrm{H}_{2}$ is different from the enzyme involved in the $\mathrm{H}_{2}$ consumption (hydrogenase) responsible for the soil uptake (Conrad, 1985).

The MATSIRO model (Minimal Advanced Treatment of Surface Interaction and RunOff) (Takata et al. 2005) was employed as the land surface process model for the CCSR/NIES/FRCGC AGCM. The model calculates water and energy exchange between land and atmosphere based on a set of 10 vegetation and eight soil types. The soil is vertically resolved by five layers with a thickness of 5,20 , 75,100 and $200 \mathrm{~cm}$ for each layer starting from the surface, and soil temperature and moisture are calculated for each layer. Surface fluxes are determined for the snow-free and snow-covered portions separately in each grid. An evaluation of MATSIRO showed that the model reproduces realistically the distributions of observed soil temperature, soil moisture, snow cover and precipitation (Koster, et al., 2004; Hirabayashi et al., 2005). By coupling the CHASER and MATSIRO models in the framework of MIROC, we have modified the dry deposition scheme used in CHASER. The stomatal conductance for each chemical tracer is calculated by using the simulated strength of photosynthesis in MATSIRO, which is based on SiB2 (Sellers et al., 1996) and a Farquhar type formulation (Farquhar et al., 1980). A new deposition pathway related to the biological consumption is described below.

\subsection{Soil uptake model}

The largest sink of tropospheric $\mathrm{H}_{2}$ is the soil uptake. Not only physical processes (e.g. molecular diffusion) but also biological processes can determine the strength of the $\mathrm{H}_{2}$ uptake by the soil. $\mathrm{H}_{2}$ consumption by soil was thought to be mainly due to abiontic enzymes (Conrad and Seiler, 1985, Conrad, 1996). Recent studies have suggested however that many kinds of bacteria can oxidize and consume $\mathrm{H}_{2}$ without enzymes, such as actinobacterias, for example (Constant et al. 2010). The intensity of the biological activity is controlled to a large extent by the soil temperature. Smith-Downey et al. (2006b) showed that an optimal activity is achieved between $20^{\circ}$ and $30^{\circ} \mathrm{C}$, and decreases with decreasing temperature below $\sim 10^{\circ} \mathrm{C}$. Considerable activity remains at subzero temperature $\left(0\right.$ to $\left.-4^{\circ} \mathrm{C}\right)$, but there is almost no uptake below $-20^{\circ} \mathrm{C}$. They also showed reduced activity above the $40^{\circ} \mathrm{C}$ to $60^{\circ} \mathrm{C}$ range in an experiment conducted with soils from a California forest. In addition to the temperature effect, biological activity is also influenced by the soil moisture content, becoming less active when the soil is arid or frozen. On the other hand, too much soil water 
reduces the porosity in the soil and restricts the diffusion of $\mathrm{H}_{2}$ into the soil. Much of the $\mathrm{H}_{2}$ in the soil is consumed at depths several centimeters below the surface, i.e. below a thin inert layer near the surface (Yonemura et al., 2000b; Schmitt et al., 2009). The inactive layer acts as a diffusion barrier, and is probably caused by the dryness and high temperature near the ground surface. Yonemura et al. (2000a) calculated the deposition velocity of $\mathrm{H}_{2}$ using a 2-layer diffusion model that incorporated the biologically inactive and active layer. Their model was able to capture the observed vertical profiles of $\mathrm{H}_{2}$ in the soil and showed that the thickness of the inactive layer is important for a realistic simulation of the flux strength. In this study, we incorporate the same type of 1-D diffusion model described in Yonemura et al. (2000a) to the deposition scheme of the CHASER model.

\subsubsection{General approaches of dry deposition in the model}

The dry deposition scheme used in the CHASER model is mainly based on the method of Wesely (1989). The deposition flux to the canopy, the soil, the snow, and sea surface of each gas is described as follows.

$F=-V_{\mathrm{d}} \times \rho C$

where $F$ is the flux of the each gas $\left(\mathrm{kg} \mathrm{m}^{-2} \mathrm{~s}^{-1}\right), V_{\mathrm{d}}$ is the deposition velocity $\left(\mathrm{m} \mathrm{s}^{-1}\right), \rho$ is the atmospheric density $\left(\mathrm{kg} \mathrm{m}^{-3}\right)$ and $C$ is the mass concentration of each gas $\left(\mathrm{kg} \mathrm{kg}^{-1}\right) . \quad V_{\mathrm{d}}$ is expressed with the reciprocal number $R$ $\left(\mathrm{s} \mathrm{m}^{-1}\right)$ using an analogy to an electrical resistance circuit. $R$ is the total resistance given as

$\mathrm{R}=\mathrm{R}_{\mathrm{a}}+\mathrm{R}_{\mathrm{b}}+\mathrm{R}_{\mathrm{c}}$

where $R_{\mathrm{a}}$ is the aerodynamic resistance, $R_{\mathrm{b}}$ is the quasilaminar (boundary layer) resistance, and $R_{\mathrm{c}}$ is the resistance to uptake by the canopy or ground surface. $R_{\mathrm{c}}$ is basically a parallel connection in the resistance and depends on the condition of the canopy/ground surface. Wesely (1989) expressed the difference in the canopy/ground surface resistance for each gas by considering the water solubility and oxidizing capacity. In this study, we calculated the deposition flux by adding a resistance term in the parallel pathway to the soil surface, $R_{\mathrm{enz}}$, to $R_{\mathrm{c}}$. $R_{\mathrm{enz}}$ is calculated by a soil diffusion/uptake model described below. This 1-D model has two layers in the uppermost layer of the MATSIRO model. We neglect $\mathrm{H}_{2}$ deposition onto snow and the ocean surfaces because of small $\mathrm{H}_{2}$ solubility. The fraction of snow cover is calculated from the depth of snow on the ground, and the total deposition flux of each gas onto the surface is determined according to the snow cover ratio.

\subsubsection{Two-layered diffusion/uptake model}

The 1-D molecular diffusion model has a depth-dependent uptake ratio. The deposition velocity on the soil surface is given by

$V_{\mathrm{d} \text { soil }}=\frac{F(z)}{\rho C(z)}, \quad z=0$

where $F(z)$ is the flux $\left(\mathrm{kg} \mathrm{m}^{-2} \mathrm{~s}^{-1}\right)$ and $C(z)$ is the mass concentration of $\mathrm{H}_{2}\left(\mathrm{~kg} \mathrm{~kg}^{-1}\right) . z(\mathrm{~m})$ is positive in the downward direction from the surface $(z=0)$, as is $F$. The uptake flux is written using Fick's Law and the mass balance of $\mathrm{H}_{2}$ is expressed as follows;

$F(z)=-D_{\mathrm{s}} \times \frac{\partial \rho C(z)}{\partial z}$

$\frac{\partial \rho C(z)}{\partial t}=\frac{\partial}{\partial z}\left(D_{\mathrm{s}} \times \frac{\partial \rho C(z)}{\partial z}\right)-k \times \rho \Theta C(z)$

where $\Theta$ is the volume of gas per unit volume of soil (air ratio, $\left.\mathrm{m}^{3} \mathrm{~m}^{-3}\right), D_{\mathrm{s}}$ is the diffusivity in the soil driven by molecular diffusion $\left(\mathrm{m}^{2} \mathrm{~s}^{-1}\right)$, and $k$ is the biological uptake rate in the soil $\left(\mathrm{s}^{-1}\right)$. In our model, we assume $\rho, \Theta$, and $D_{\mathrm{s}}$ to be uniform from the soil surface to a sufficient depth. In addition, we include an inactive layer near the surface where no biological activity takes place. We adopted a simplified depth-dependent distribution of biological activity $k(z)$ as;

$k(z)=0 \quad$ at $0<z<\delta$

$k(z)=k_{0} \quad$ at $\delta<z$

where $k_{0}$ is the uptake rate $\left(\mathrm{s}^{-1}\right)$, a constant value below $\delta$ (m) within the uppermost layer of MATSIRO model. Since the $\mathrm{H}_{2}$ uptake is relatively fast and occurs in the top soil, we assumed a steady state. We defined the $\mathrm{H}_{2}$ concentration at depth $z=0$ as $C_{\mathrm{a}}$ and $z=\delta$ as $C_{\delta}$. The concentration in the inactive layer $C_{i l}(z)$ can be solved using Eq. (5), Eq. (6), and the boundary condition as:

$C_{\mathrm{il}}(z)=\frac{C_{\delta}-C_{\mathrm{a}}}{\delta} z+C_{\mathrm{a}}$

The concentration in the active layer $C_{\mathrm{al}}(z)$ can also be solved by

$C_{\mathrm{al}}(z)=\frac{C_{\delta}}{e^{-f}} \times e^{\left(-\frac{f}{\delta} z\right)}$

where $f=\delta \sqrt{\frac{k}{D_{\mathrm{s}}}}$. With the condition that the flux in the boundary $F(z=\delta)$ between the two layers is equal, $C_{\delta}$ can be given using Eq. (4), Eq. (8), Eq. (9) as

$C_{\delta}=\frac{1}{1+f} C_{\mathrm{a}}$. 
The deposition velocity on the surface of the inactive layer is given by

$V_{\mathrm{d} \text { soil }}=\frac{1}{1+f} \Theta \sqrt{k D_{\mathrm{s}}}=\frac{\Theta D_{\mathrm{s}} \sqrt{k}}{\sqrt{D_{\mathrm{s}}}+\delta \sqrt{k}}$.

Equation (11) shows that the thickness of the inactive layer $\delta$ is an important parameter in the reduction of the soil uptake flux, compared with a case without an inactive layer. When the diffusivity in the soil is increased, the effect of the inactive layer becomes weaker. On the other hand, the influence of the inactive layer becomes greater as the biological activity increases.

The gas diffusion into the soil airspace is assumed to be driven by molecular diffusion. The soil gas diffusivity $D_{\mathrm{s}}$ can be expressed as an approximation using the MillingtonQuirk model (Millington and Quirk, 1959):

$D_{\mathrm{s}}=D_{\mathrm{a}} \frac{\Theta^{3.1}}{\Theta_{\text {sat }}^{2}}$

where $D_{\mathrm{a}}$ is the molecular diffusion coefficient of each gas in the atmosphere, and $\Theta_{\text {sat }}$ is the maximum aerial or liquid water volume per unit volume of soil (total porosity). In the land process model, the total porosity is given for each soil type at each grid, and the presence of liquid water and ice limits the diffusion of the gas in the soil. The biological uptake rate of $\mathrm{H}_{2}$ is determined not only by the degree of activity of each enzyme, but also by the amount of enzyme present. However, global distributions of the $\mathrm{H}_{2}$-consumption enzymes/bacteria present have yet to be elucidated quantitatively. For example, Smith-Downey et al. (2006b) showed that fresh litter on the forest floor prevents efficient absorption of $\mathrm{H}_{2}$ by the soil. Also, although the amount of organic matter and $\mathrm{pH}$ of the soil influence the amount of enzyme present, previous investigations have shown that these do not appear to moderate the activity greatly (Smith-Downey et al. 2008). In this study, we model the variation in the biological activity as a function of soil temperature and moisture, in accordance with the relationship obtained by Smith-Downey et al. (2006a, b).

$k_{0}=k_{\max } \times f(T) \times f(\Theta)$

$f(T)=\frac{1}{1+\exp (-0.1718 \times T+46.938)}$

$f(M)=\left\{\begin{array}{rr}1 & M>0.15 \\ 14.3 M-1.14 & 0.15 \geq M \geq 0.08 \\ 0 & M<0.08\end{array}\right.$

$M=\frac{\Theta_{\mathrm{w}}}{\Theta_{\text {sat }}}$

where $k_{\max }$ is the maximum uptake rate and is assigned a value of $0.1227 \mathrm{~s}^{-1}$ estimated by Smith-Downey et al. (2006a). $M$ is the ratio of liquid water volume per unit volume of soil $\left(\Theta_{\mathrm{W}}\right)$ to $\Theta_{\text {sat }}$. In our model, the soil temperature $T(\mathrm{~K})$ and moisture is obtained from the uppermost soil layer for the calculation of $k_{0}$.
As mentioned above, the inactive layer thickness $\delta$ is an influential model parameter, but its global distribution is not well known. Yonemura et al. (2000b) suggested $\delta$ in a range of $0-1 \mathrm{~cm}$ from their experimental result. Schmitt et al. (2009) estimated $\delta$ to be around $0.7 \mathrm{~cm}$, with a range of $0.3-1.8 \mathrm{~cm}$, based on observations at a site in Heidelberg. In this study, we use a uniform $\delta$ of $0.7 \mathrm{~cm}$ to achieve a good agreement with global observations (see Sect. 3.3 below).

\section{Results and discussion}

\subsection{Deposition velocity and soil uptake of $\mathbf{H}_{2}$}

The distribution of the calculated surface deposition velocity of $\mathrm{H}_{2}$, the diffusivity in the soil and the uptake rate due to enzyme activity for January and July are shown in Fig. 1. For the period 1997-2005, the globally averaged deposition velocity over the land surface is $0.33 \times 10^{-2} \mathrm{~cm} \mathrm{~s}^{-1}$, but is characterized by a clear geographical distribution and temporal variation, particularly in regions north of $45^{\circ} \mathrm{N}$. During the winter season, snow cover suppresses soil absorption, compounding the reduction in the rate of deposition due to a decreased biological activity. Although the enzyme activity is still maintained near freezing point, biological activity in areas like Siberia stops when the soil temperature falls below $-25^{\circ} \mathrm{C}$; this is also due to a significant reduction in the enzyme activity caused by the freezing of soil moisture. With the arrival of boreal spring, the deposition velocity starts to increase and the uptake region rapidly expands to regions north of $50^{\circ} \mathrm{N}$, as soil temperature increases and snow melts. The deposition velocity in these regions reaches a maximum during July and August, and then starts to decrease with the coming of the autumn and winter seasons. In several parts of the region north of $45^{\circ} \mathrm{N}$, the increase in deposition velocity during the spring and summer is interrupted due to a reduction in the soil gas diffusivity caused by an increase in soil moisture from spring snowmelt and summer melting of soil ice.

In the latitude zone around $30^{\circ} \mathrm{N}$, the temperature is sufficiently high for enzymes/bacteria to be active throughout the year and the soil moisture becomes more important in controlling the deposition velocity. In a desert area where there is very little moisture, the deposition velocity is near zero because of the near absence of biological activity. Semi-arid regions like Central Asia and the central part of the North American continent show larger deposition velocities during the winter than during the summer. The dryness makes diffusion in the soil more efficient in taking up $\mathrm{H}_{2}$ in these areas. However, for intensely high temperatures and increased dryness in the summer, the biological activity becomes weaker and soil uptake is suppressed. Although in temperate and humid areas such as south China, there is neither dryness nor high temperature stress, the $\mathrm{H}_{2}$ uptake can be reduced by 

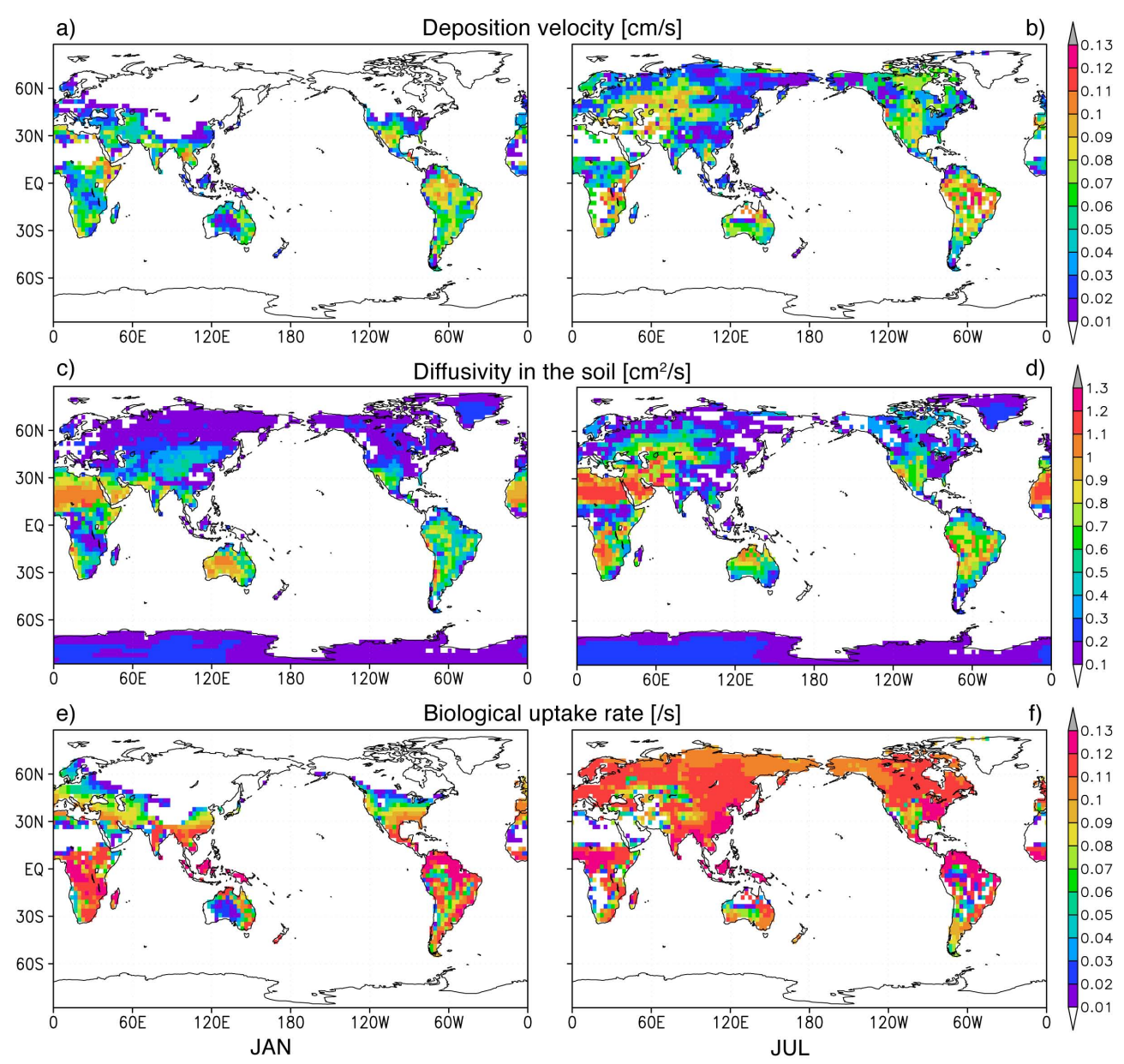

Fig. 1. Monthly mean distribution of simulated deposition velocity (a, b), diffusivity in the soil (c, d), and the uptake rate of biological $\mathrm{H}_{2}$-consumption (e, f) for January and July. The values are averaged over the period 1997-2005.

high soil moisture that suppresses gas diffusion through the soil.

Seasonal variations in the deposition velocity in the tropics and in the Southern Hemisphere have relatively small amplitudes. The amount of soil moisture has a major influence on the deposition velocity in regions $20^{\circ} \mathrm{N}$ to $30^{\circ} \mathrm{S}$; therefore, a spatial change in the deposition strength is a function of the shift between the rainy and dry seasons. Southern high latitude regions do not make significant contributions to the $\mathrm{H}_{2}$ uptake because, in addition to the very little land area in these regions, Antarctica is mostly covered by snow and exhibits almost no deposition.

Regional and seasonal changes in the soil uptake rates obtained from some field observations have been reported. (See the summarized list in Ehhalt and Rohrer (2009), Table 6). Although the coarseness of the model grid resolution makes it difficult to make a direct comparison between the simulated and observed deposition velocities, we can perform a rough comparison if the point observation is representative of a larger region. Conrad and Seiler (1980) conducted a year- round observation on the grassland near Mainz, Germany from 1978 to 1979 . They reported a seasonal variation in the deposition velocity in the range of 2.6 to $8.8 \times 10^{-2} \mathrm{~cm} \mathrm{~s}^{-1}$ with a maximum between May and October and a minimum between December and February. Similar results were obtained from the observations made at grasslands and cultivated lands near their site. In order to compare our model value with their observed value, we choose a grid point that spatially corresponds to their cultivated land. For the period between November and April, a simulated deposition velocity of $\sim 5 \times 10^{-2} \mathrm{~cm} \mathrm{~s}^{-1}$ agrees with their results. During the warm season, the calculated deposition velocity has a large variation in the range of $5-10 \times 10^{-2} \mathrm{~cm} \mathrm{~s}^{-1}$ that is associated with the variation in precipitation and is comparable with the range of observed values. The deposition velocity observed by Smith-Downey et al. (2006b) for desert scrubland in Southern California showed a steep seasonal change. Our model is able to capture a similar variation in the semiarid ecosystem region of the south-western North America. Both the observed and modeled deposition velocities reach a 


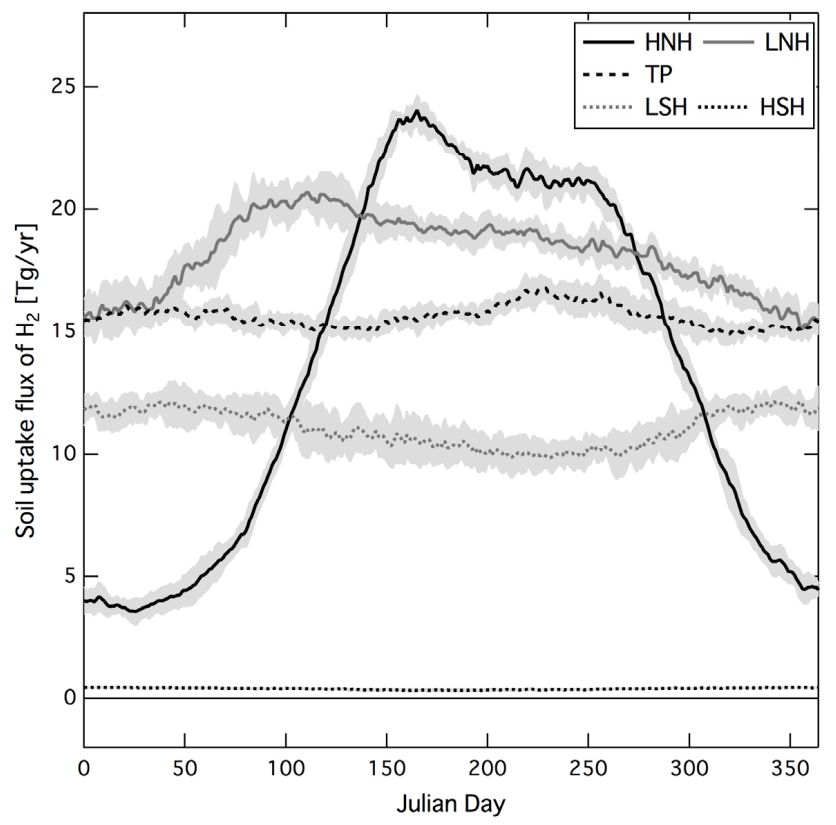

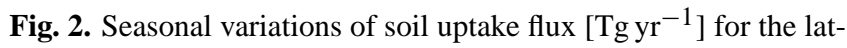
itudinal range north of $45^{\circ} \mathrm{N}(\mathrm{HNH}), 45^{\circ} \mathrm{N}$ to $15^{\circ} \mathrm{N}(\mathrm{LNH}), 15^{\circ} \mathrm{N}$ to $15^{\circ} \mathrm{S}$ (TP), $15^{\circ} \mathrm{S}$ to $45^{\circ} \mathrm{S}$ (LSH), and south of $45^{\circ} \mathrm{S}$ (HSH). Shaded areas are the standard deviation for the multi-year average, which arise from both the day-to-day variation and inter-annual variation of the flux.

maximum in early spring with a value of $\sim 9 \times 10^{-2} \mathrm{~cm} \mathrm{~s}^{-1}$, falling thereafter to a value of $2-4 \times 10^{-2} \mathrm{~cm} \mathrm{~s}^{-1}$ in June. The rapid decrease is caused by water stress on the biological activity. In the northern high-latitudes, observations at a forest site in Finland by Lallo et al. (2006) showed low deposition velocity values $\left(0-4 \times 10^{-2} \mathrm{~cm} \mathrm{~s}^{-1}\right)$ in the winter and high values $\left(4-7 \times 10^{-2} \mathrm{~cm} \mathrm{~s}^{-1}\right)$ in snow-free seasons. Our model simulation agrees relatively well with these observations, producing a seasonal cycle with an amplitude range of $0-6 \times 10^{-2} \mathrm{~cm} \mathrm{~s}^{-1}$. For an arable field in Japan, Yonemura et al. (2000b) performed a year-round observation and obtained seasonally-varying deposition velocities in the range of $0-10 \times 10^{-2} \mathrm{~cm} \mathrm{~s}^{-1}$. However, our model shows a constant value of $2 \times 10^{-2} \mathrm{~cm} \mathrm{~s}^{-1}$, without a seasonal cycles, due to the coarseness of the model grid to resolve the arable land in Japan.

The seasonal variations in the soil uptake for the five latitudinal bands are shown in Fig. 2. North of $45^{\circ} \mathrm{N}(\mathrm{HNH})$, the averaged $\mathrm{H}_{2}$ uptake flux has a broad maximum of 21$24 \mathrm{Tg} \mathrm{yr}^{-1}$ during the period between June and August. In September, the flux begins to decrease and reaches a value of $\sim 5 \mathrm{Tg} \mathrm{yr}^{-1}$ in January. From March to May, a rapid increase of the flux is seen. In the latitude band between $15^{\circ} \mathrm{N}$ and $45^{\circ} \mathrm{N}(\mathrm{LNH})$, the flux remains relatively high throughout the year, increasing from $15 \mathrm{Tg} \mathrm{yr}^{-1}$ in February to $20 \mathrm{Tg} \mathrm{yr}^{-1}$ in May, and then decreasing gradually thereafter to Decem- ber. In the tropics (TP), the flux shows an almost a constant value of $15 \mathrm{Tg} \mathrm{yr}^{-1}$ throughout the year. In latitudes between $15^{\circ} \mathrm{S}$ and $45^{\circ} \mathrm{S}$ (LSH), the flux has a small seasonal variation. The maximum and minimum values obtained are 11 and $10 \mathrm{Tg} \mathrm{yr}^{-1}$ in the austral winter and summer, respectively. Almost no uptake is seen south of $45^{\circ} \mathrm{S}$ due to the lack of snow-free land surfaces. In LNH and LSH, variation in the soil moisture is the dominant factor that governs the deposition velocity and the soil uptake. The soil moisture content is controlled by the rainfall associated with synoptic systems, producing relatively large day-to-day variations in the uptake flux.

\subsection{Comparison with the observed $\mathrm{H}_{2}$}

We compare the simulated $\mathrm{H}_{2}$ mixing ratio with observation from the National Oceanic and Atmospheric Administration (NOAA)/Earth System Research Laboratory (ESRL) network (Novelli et al., 1999). A summary of modelobservation comparisons is given in Table 1 together with an explanation of the abbreviated name of each station. The time series of the observed $\mathrm{H}_{2}$ mixing ratios for 10 selected stations are shown in Fig. 3 and those of the calculated daily mean values are appended. The observed values at some sites show a large decrease in the mixing ratios from 1991 to 1993 (not shown). Previous studies on $\mathrm{CH}_{4}$ and $\mathrm{CO}$ pointed to the fact that the variation during this period could be partly attributable to the effects of the Mt. Pinatubo eruption in June 1991. Our model does not consider the effect of Mt. Pinatubo, and no large inter-annual variation is reproduced by the model for this period. Furthermore, our model uses the climatology for biomass burning emissions before 1996, resulting in some discrepancies with the observations. We therefore focus our comparison during the period between 1997 and 2005. To extract the annual average, the averaged seasonal cycle, and the long-term variation, we calculate a best-fitted curve to the data using the method of Nakazawa et al. (1997).

In general, the model reproduces the observed $\mathrm{H}_{2}$ mixing ratio well. In Fig. 3, the overall patterns of seasonal cycles and inter-annual variation calculated by the model are in relatively good agreement with those obtained at many of the observation stations. The differences between the observed and fitted curve indicate short-term fluctuations comparable to the day-to-day variations. From Table 1, we see that the overall averaged comparison bias is $0.2 \%$. Averaged values of the Pearson's moment correlations for the daily mean data at many stations is 0.75 . (Comparisons using monthly mean values show better correlations.) But several stations show noticeable discrepancies in the averaged mixing ratio and/or in correlation coefficient. Take Tutuila, American Samoa (SMO) for example: the calculated mixing ratio for SMO from the model agrees with the lower values observed during the period 1997 to 2002. After 2003, the observed and simulated mixing ratios agree relatively well. There are no large, 


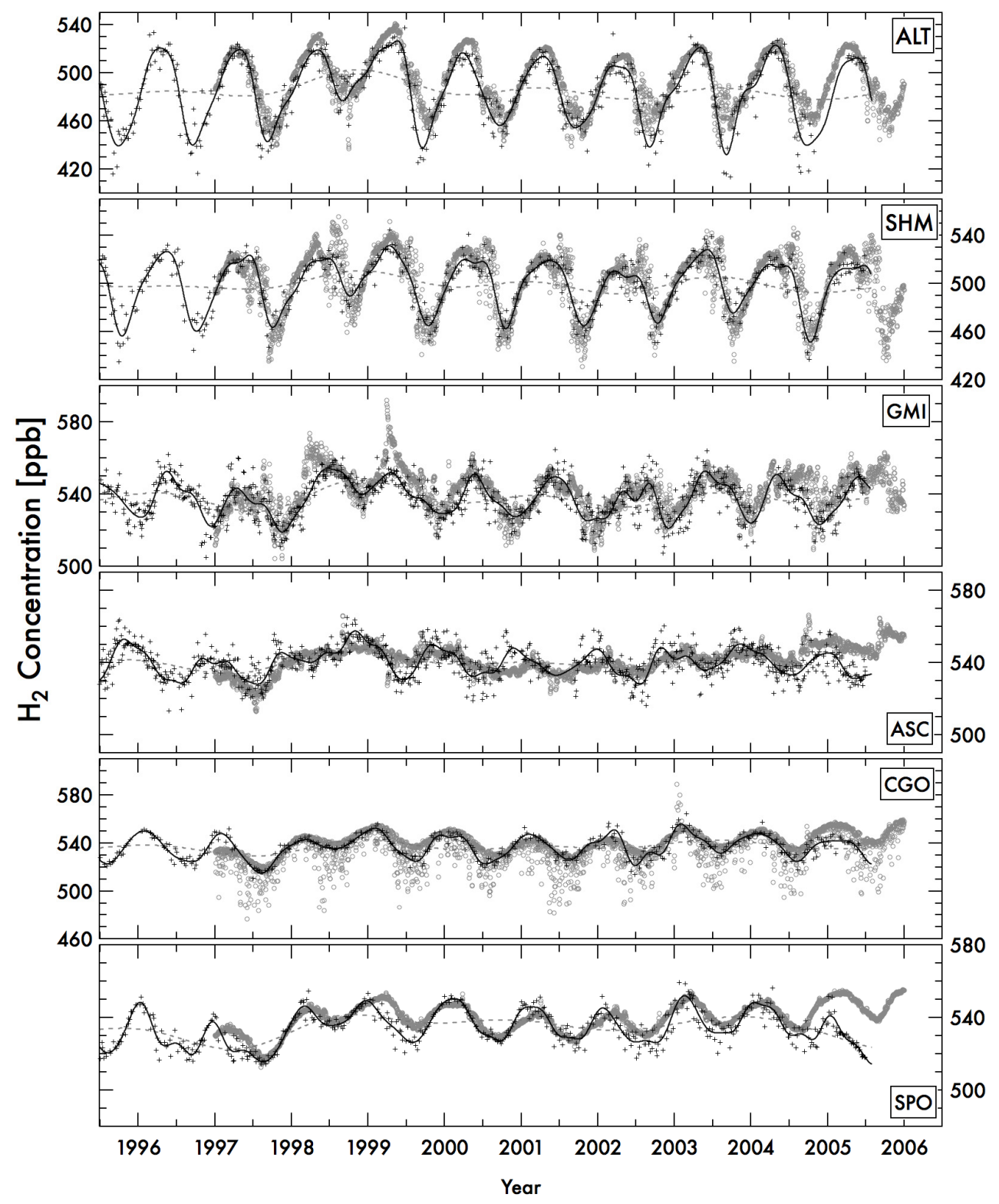

Fig. 3a. $\mathrm{H}_{2}$ mixing ratios at selected observation sites; $\operatorname{ALT}\left(82.5^{\circ} \mathrm{N}\right), \operatorname{SHM}\left(52.7^{\circ} \mathrm{N}\right), \operatorname{GMI}\left(13.4^{\circ} \mathrm{N}\right), \operatorname{ASC}\left(7.9^{\circ} \mathrm{S}\right), \mathrm{CGO}^{\circ}\left(40.7^{\circ} \mathrm{S}\right)$, and $^{\circ}$ $\mathrm{SPO}\left(90.0^{\circ} \mathrm{S}\right)$. Abbreviations for each site are expressed in Table 1. Black circles are the observed values, dotted lines are the best fit curves to the data, dashed lines are the long-term trends, and gray circles are the values calculated using the CHASER model.

strong sources of $\mathrm{H}_{2}$, which cover the wide area around the SMO station, and the mixing ratio in the free troposphere is below $600 \mathrm{ppb}$, leading to the possibility of local contamination. Similarly, Tae-ahn Peninsula, Republic of Korea (TAP) shows less agreement in the statistical comparison, likely due to the effect of strong local emissions.

For Cape Grim, Australia (CGO), the comparison between the observed and calculated value shows good agreement (Table 1). However, the time series of simulated value is characterized by spikes of low values, in disagreement with the observations. This difference is likely caused by the se- lective sampling procedure employed at this station in an effort to obtain "background" mixing ratio levels. Since the sampling is based on the wind direction to collect maritime air, the air mass arriving from the Australian continental side is removed. This leads to a general rising of the observed $\mathrm{H}_{2}$ mixing ratio at CGO since the $\mathrm{H}_{2}$ in air from the Australian continent is lower than oceanic air because of strong soil uptake. When the same selection procedure is applied to the model result, the low values in the time series at CGO are removed. Comparisons with other stations are discussed below. 


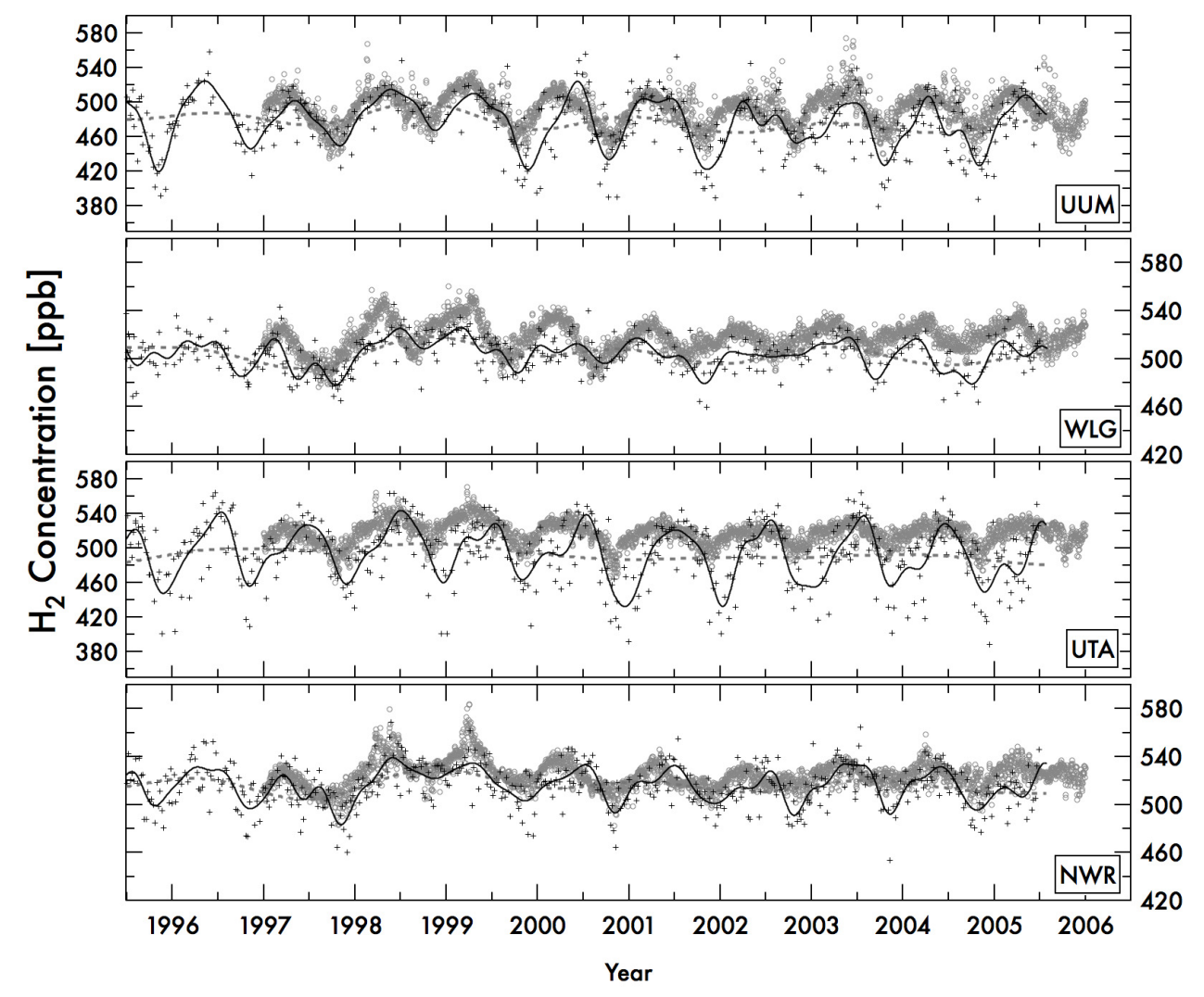

Fig. 3b. Same as Fig. 3a, but for UUM $\left(44.5^{\circ} \mathrm{N}\right), \operatorname{WLG}\left(36.3^{\circ} \mathrm{N}, 3810 \mathrm{~m}\right), \mathrm{UTA}\left(39.9^{\circ} \mathrm{N}\right), \mathrm{NWR}\left(40.0^{\circ} \mathrm{N}, 3523 \mathrm{~m}\right)$

\subsubsection{Seasonal cycles}

Monthly mean values from the 10 selected stations are shown in Fig. 4. The latitudinal distributions of the seasonal maximum and minimum and the timing of their occurrences are shown in Fig. 5. Consistent with previous studies, the seasonal cycle amplitudes are large at the Northern Hemisphere high latitudes and decrease towards the tropics. The amplitudes in the Southern Hemisphere extra-tropics are slightly larger than those in the tropics, but smaller than those of the Northern Hemisphere extra-tropics. The upper right panel in Fig. 5 shows that the model reproduces the amplitude distribution relatively well, and that the latitudinal distribution of the seasonal minimum is a major contributor to the northsouth gradient.

For regions south of $30^{\circ} \mathrm{S}$, the phase and amplitude of the seasonal variation are similar between the stations, with the maximum and minimum occurring in the austral summer and winter, respectively. Since the regional contrast of sources and sinks is small and the lifetime is longer than the timescale of transport and mixing, $\mathrm{H}_{2}$ is relatively well mixed globally. The homogeneous distribution also results in smaller synoptic variation (See the result for the South Pole (SPO) in Fig. 4), excluding at CGO for reasons discussed above. Novelli et al. (1999) and Hauglustaine and Ehhalt (2002) pointed out that the main influence on the seasonal cycle in the Southern Hemisphere comes from biomass burning. On the other hand, based on their airborne observations of $\mathrm{H}_{2}$ and its $\delta D$ ratio, Rhee et al. (2006) noted that the variation in the chemical production is also a dominant factor. For $\mathrm{CO}$, seasonal maxima appear during the austral spring in the southern high latitudes and are prominently connected to the timing of maximum biomass burning emissions in Southern Africa and Southern America. But the seasonal maxima for $\mathrm{H}_{2}$ occur later than those of CO. In the Southern Hemisphere, the seasonal maximum and minimum for the net chemical production appear in the austral summer and winter, respectively, and the phasing of the $\mathrm{H}_{2}$ seasonal cycle is linked to this rather than to the variation in the biomass burning activities. We therefore conclude that the net chemical production is the more dominant process influencing the $\mathrm{H}_{2}$ seasonal cycle in the southern high latitudes. However, it is possible that biomass burning can shift the timing of the occurrence of this seasonal maximum. For example, the model simulation reproduces the shape and magnitude of the seasonal cycle at each of the stations in this region of the Southern Hemisphere well, but the seasonal maximum occurs about one month later than for the observations. The timing of seasonal maximum in our model could be caused by the weak biomass burning emissions in the Southern Hemisphere. 
Table 1. Averaged mixing ratios, the amplitude of the seasonal cycles, and Pearson's moment correlations between observed and simulated values for all sites considered in this study.

\begin{tabular}{|c|c|c|c|c|c|c|c|c|c|c|}
\hline \multicolumn{3}{|c|}{ SITE } & \multirow{2}{*}{$\begin{array}{c}\text { Datapoints for } \\
\text { comparison }^{\mathrm{a}}\end{array}$} & \multicolumn{3}{|c|}{ Mean Conc. } & \multicolumn{3}{|c|}{ Amplitude of Season. Cycle ${ }^{c}$} & \multirow[t]{2}{*}{ Corr. Coef } \\
\hline abbr & Name (Latitude, Longitude, Elevation) & Period & & Obs. & Model & $\operatorname{Bias}[\%]^{\mathrm{b}}$ & Obs. & Model & Ratio $[\%]^{\mathrm{d}}$ & \\
\hline ALT & $\operatorname{Alert}\left(82.5^{\circ} \mathrm{N}, 62.5^{\circ} \mathrm{W}, 210 \mathrm{~m}\right)$ & $1997 / 01-2005 / 06$ & 1328 & 488.2 & 495.1 & 1.4 & 71.6 & 59.5 & 83 & 0.84 \\
\hline ASC & Ascension Island $\left(7.9^{\circ} \mathrm{S}, 14.4^{\circ} \mathrm{W}, 54 \mathrm{~m}\right)$ & 1997/01-2005/06 & 1467 & 540.3 & 541.1 & 0.1 & 14.9 & 7.4 & 50 & 0.38 \\
\hline ASK & Assekrem $\left(23.3^{\circ} \mathrm{N}, 5.6^{\circ} \mathrm{E}, 2710 \mathrm{~m}\right)$ & 1997/01-2005/06 & 600 & 541.2 & 523.4 & -3.3 & 21.1 & 25.2 & 120 & 0.31 \\
\hline AZR & Terceira Island $\left(38.8^{\circ} \mathrm{N}, 27.4^{\circ} \mathrm{W}, 40 \mathrm{~m}\right)$ & $1997 / 01-2005 / 05$ & 630 & 510.6 & 516.1 & 1.1 & 30.5 & 38.4 & 126 & 0.60 \\
\hline BAL & Baltic Sea $\left(55.4^{\circ} \mathrm{N}, 17.2^{\circ} \mathrm{E}, 28 \mathrm{~m}\right)$ & 1997/01-2005/06 & 1456 & 510.7 & 499.6 & -2.2 & 39.6 & 43.6 & 110 & 0.68 \\
\hline BME & St. David's Head $\left(32.4^{\circ} \mathrm{N}, 64.7^{\circ} \mathrm{W}, 30 \mathrm{~m}\right)$ & 1997/01-2005/06 & 657 & 523.6 & 519.8 & -0.7 & 38.3 & 40.7 & 106 & 0.62 \\
\hline BMW & Tudor Hill $\left(32.3^{\circ} \mathrm{N}, 64.9^{\circ} \mathrm{W}, 30 \mathrm{~m}\right)$ & 1997/01-2005/06 & 632 & 527.6 & 521.6 & -1.1 & 39.6 & 41.0 & 104 & 0.69 \\
\hline BRW & Barrow $\left(71.3^{\circ} \mathrm{N}, 156.6^{\circ} \mathrm{W}, 11 \mathrm{~m}\right)$ & 1997/01-2005/07 & 1815 & 493.5 & 493.9 & 0.1 & 61.9 & 60.6 & 98 & 0.81 \\
\hline BSC & Black Sea $\left(44.2^{\circ} \mathrm{N}, 28.7^{\circ} \mathrm{E}, 3 \mathrm{~m}\right)$ & 1997/01-2005/06 & 803 & 525.7 & 494.1 & -6.0 & 53.9 & 38.7 & 72 & 0.36 \\
\hline CBA & Cold Bay $\left(55.2^{\circ} \mathrm{N}, 162.7^{\circ} \mathrm{W}, 25 \mathrm{~m}\right)$ & $1997 / 01-2005 / 07$ & 1639 & 499.5 & 503.8 & 0.9 & 51.2 & 59.7 & 116 & 0.79 \\
\hline CGO & Cape Grim $\left(40.7^{\circ} \mathrm{S}, 144.7^{\circ} \mathrm{E}, 94 \mathrm{~m}\right)$ & 1997/01-2005/06 & 806 & 536.7 & 539.8 & 0.6 & 21.7 & 17.9 & 82 & 0.68 \\
\hline $\mathrm{CHR}$ & Christmas Island $\left(1.7^{\circ} \mathrm{N}, 157.2^{\circ} \mathrm{W}, 3 \mathrm{~m}\right)$ & 1997/01-2005/06 & 537 & 544.3 & 543.2 & -0.2 & 12.7 & 11.3 & 90 & 0.26 \\
\hline CRZ & Crozet $\left(46.5^{\circ} \mathrm{S}, 51.9^{\circ} \mathrm{E}, 120 \mathrm{~m}\right)$ & $1997 / 01-2005 / 06$ & 523 & 535.8 & 540.4 & 0.9 & 17.4 & 17.2 & 99 & 0.42 \\
\hline EIC & Easter Island $\left(27.1^{\circ} \mathrm{S}, 109.5^{\circ} \mathrm{W}, 50 \mathrm{~m}\right)$ & 1997/01-2005/06 & 565 & 541.7 & 540.5 & -0.2 & 19.8 & 13.0 & 66 & 0.41 \\
\hline GMI & $\operatorname{Guam}\left(13.4^{\circ} \mathrm{N}, 144.8^{\circ} \mathrm{E}, 2 \mathrm{~m}\right)$ & 1997/01-2005/06 & 1538 & 538.6 & 541.2 & 0.5 & 20.5 & 21.6 & 105 & 0.59 \\
\hline HBA & Halley Bay $\left(75.6^{\circ} \mathrm{S}, 26.5^{\circ} \mathrm{W}, 33 \mathrm{~m}\right)$ & 1997/01-2005/06 & 818 & 538.0 & 539.5 & 0.3 & 20.9 & 18.1 & 87 & 0.53 \\
\hline HUN & Hegyhatsal $\left(47.0^{\circ} \mathrm{N}, 16.7^{\circ} \mathrm{E}, 248 \mathrm{~m}\right)$ & 1997/01-2005/06 & 793 & 520.3 & 505.3 & -2.9 & 41.5 & 36.6 & 88 & 0.67 \\
\hline ICE & Heimaey $\left(63.4^{\circ} \mathrm{N}, 20.3^{\circ} \mathrm{W}, 100 \mathrm{~m}\right)$ & $1997 / 01-2005 / 06$ & 728 & 500.3 & 494.3 & -1.2 & 49.4 & 50.8 & 103 & 0.77 \\
\hline ITN & Grifton $\left(35.4^{\circ} \mathrm{N}, 77.4^{\circ} \mathrm{W}, 505 \mathrm{~m}\right)$ & 1997/01-1999/06 & 262 & 530.4 & 521.0 & -1.8 & 50.1 & 41.8 & 84 & 0.73 \\
\hline IZO & Tenerife $\left(28.3^{\circ} \mathrm{N}, 16.5^{\circ} \mathrm{W}, 2360 \mathrm{~m}\right)$ & $1997 / 01-2005 / 06$ & 669 & 531.4 & 523.0 & -1.6 & 25.6 & 25.4 & 99 & 0.52 \\
\hline KEY & Key Biscayne $\left(25.7^{\circ} \mathrm{N}, 80.2^{\circ} \mathrm{W}, 3 \mathrm{~m}\right)$ & 1997/01-2005/06 & 655 & 545.6 & 532.1 & -2.5 & 36.1 & 33.7 & 93 & 0.35 \\
\hline KUM & Cape Kumukahi $\left(19.5^{\circ} \mathrm{N}, 154.8^{\circ} \mathrm{W}, 3 \mathrm{~m}\right)$ & 1997/01-2005/06 & 1734 & 511.4 & 529.6 & 3.6 & 28.9 & 29.7 & 103 & 0.66 \\
\hline KZD & Sary Taukum $\left(44.5^{\circ} \mathrm{N}, 75.6^{\circ} \mathrm{E}, 412 \mathrm{~m}\right)$ & 1997/10-2005/06 & 701 & 452.6 & 488.3 & 7.9 & 103.1 & 35.1 & 34 & 0.48 \\
\hline KZM & Plateau Assy $\left(43.3^{\circ} \mathrm{N}, 77.9^{\circ} \mathrm{E}, 2519 \mathrm{~m}\right)$ & 1997/10-2005/06 & 707 & 498.4 & 510.2 & 2.4 & 19.2 & 31.9 & 166 & 0.23 \\
\hline LEF & Park Falls $\left(45.9^{\circ} \mathrm{N}, 90.3^{\circ} \mathrm{W}, 868 \mathrm{~m}\right)$ & 1997/01-2005/06 & 872 & 494.9 & 496.3 & 0.3 & 57.7 & 46.3 & 80 & 0.75 \\
\hline MHD & Mace Head $\left(53.3^{\circ} \mathrm{N}, 9.9^{\circ} \mathrm{W}, 25 \mathrm{~m}\right)$ & $1997 / 01-2005 / 06$ & 754 & 512.5 & 509.0 & -0.7 & 44.0 & 46.4 & 106 & 0.83 \\
\hline MID & Sand Island $\left(28.2^{\circ} \mathrm{N}, 177.4^{\circ} \mathrm{W}, 8 \mathrm{~m}\right)$ & 1997/01-2005/06 & 801 & 526.6 & 527.3 & 0.1 & 34.6 & 33.8 & 98 & 0.78 \\
\hline MLO & Mauna Loa $\left(19.5^{\circ} \mathrm{N}, 155.6^{\circ} \mathrm{W}, 3397 \mathrm{~m}\right)$ & 1997/01-2005/06 & 1666 & 531.9 & 533.3 & 0.3 & 20.7 & 20.8 & 101 & 0.49 \\
\hline NWR & Niwot Ridge $\left(40.1^{\circ} \mathrm{N}, 105.6^{\circ} \mathrm{W}, 3523 \mathrm{~m}\right)$ & $1997 / 01-2005 / 06$ & 849 & 516.0 & 524.9 & 1.7 & 25.9 & 18.7 & 72 & 0.54 \\
\hline PSA & Palmer Station $\left(64.9^{\circ} \mathrm{S}, 64.0^{\circ} \mathrm{W}, 10 \mathrm{~m}\right)$ & 1997/01-2005/06 & 798 & 536.4 & 539.9 & 0.7 & 23.2 & 18.5 & 80 & 0.69 \\
\hline RPB & Ragged Point $\left(13.2^{\circ} \mathrm{N}, 59.4^{\circ} \mathrm{W}, 45 \mathrm{~m}\right)$ & 1997/01-2005/06 & 778 & 538.9 & 530.5 & -1.6 & 20.2 & 19.5 & 97 & 0.56 \\
\hline SEY & Mahe Island $\left(4.7^{\circ} \mathrm{S}, 55.2^{\circ} \mathrm{E}, 7 \mathrm{~m}\right)$ & 1997/01-2005/06 & 747 & 544.0 & 544.3 & 0.1 & 21.7 & 10.1 & 46 & 0.47 \\
\hline SHM & Shemya Island $\left(52.7^{\circ} \mathrm{N}, 174.1^{\circ} \mathrm{E}, 40 \mathrm{~m}\right)$ & 1997/01-2005/06 & 810 & 500.9 & 503.2 & 0.5 & 51.8 & 60.6 & 117 & 0.87 \\
\hline SMO & Tutuila $\left(14.2^{\circ} \mathrm{S}, 170.6^{\circ} \mathrm{W}, 42 \mathrm{~m}\right)$ & 1997/01-2005/06 & 1434 & 556.1 & 543.8 & -2.2 & 17.1 & 8.8 & 52 & 0.01 \\
\hline SPO & South Pole $\left(90.0^{\circ} \mathrm{S}, 24.8^{\circ} \mathrm{W}, 2810 \mathrm{~m}\right)$ & 1997/01-2005/06 & 1332 & 535.5 & 535.9 & 0.1 & 18.9 & 16.7 & 88 & 0.46 \\
\hline STM & Ocean Station " $M$ " $\left(66.0^{\circ} \mathrm{N}, 2.0^{\circ} \mathrm{E}, 5 \mathrm{~m}\right)$ & 1997/01-2005/07 & 1577 & 506.5 & 501.4 & -1.0 & 43.2 & 50.3 & 116 & 0.83 \\
\hline SYO & Syowa Station $\left(69.0^{\circ} \mathrm{S}, 39.6^{\circ} \mathrm{E}, 21 \mathrm{~m}\right)$ & 1997/01-2005/06 & 392 & 538.2 & 539.4 & 0.2 & 21.8 & 17.6 & 81 & 0.56 \\
\hline TAP & Tae-ahn Peninsula $\left(36.7^{\circ} \mathrm{N}, 126.1^{\circ} \mathrm{E}, 20 \mathrm{~m}\right)$ & 1997/01-2005/06 & 801 & 529.3 & 548.0 & 3.5 & 76.2 & 51.1 & 67 & 0.59 \\
\hline TDF & Tierra del Fuego $\left(54.9^{\circ} \mathrm{S}, 68.5^{\circ} \mathrm{W}, 20 \mathrm{~m}\right)$ & $1997 / 05-2005 / 05$ & 219 & 535.9 & 537.7 & 0.3 & 22.6 & 17.3 & 76 & 0.77 \\
\hline UTA & Wendover $\left(39.9^{\circ} \mathrm{N}, 113.7^{\circ} \mathrm{W}, 1320 \mathrm{~m}\right)$ & 1997/01-2005/06 & 792 & 492.4 & 518.0 & 5.2 & 77.4 & 26.9 & 35 & 0.44 \\
\hline UUM & Ulaan $\operatorname{Uul}\left(44.5^{\circ} \mathrm{N}, 111.1^{\circ} \mathrm{E}, 914 \mathrm{~m}\right)$ & 1997/01-2005/06 & 824 & 476.4 & 492.8 & 3.4 & 66.0 & 44.0 & 67 & 0.51 \\
\hline WIS & Sede Boker $\left(31.1^{\circ} \mathrm{N}, 34.9^{\circ} \mathrm{E}, 400 \mathrm{~m}\right)$ & $1997 / 01-2005 / 07$ & 860 & 521.5 & 515.7 & -1.1 & 35.7 & 27.7 & 78 & 0.57 \\
\hline WLG & Mt. Waliguan $\left(36.3^{\circ} \mathrm{N}, 100.9^{\circ} \mathrm{E}, 3810 \mathrm{~m}\right)$ & 1997/01-2005/07 & 577 & 504.6 & 518.7 & 2.8 & 23.7 & 28.8 & 122 & 0.48 \\
\hline \multirow[t]{2}{*}{ ZEP } & Zeppelinfjellet $\left(78.9^{\circ} \mathrm{N}, 11.9^{\circ} \mathrm{E}, 475 \mathrm{~m}\right)$ & $1997 / 01-2005 / 06$ & 1005 & 496.7 & 498.3 & 0.3 & 50.5 & 55.7 & 110 & 0.80 \\
\hline & Total & 1997/01-2005/06 & 40043 & 518.5 & 519.6 & 0.2 & & & & 0.75 \\
\hline
\end{tabular}

a The individual observed value is compared with the daily average output of the model calculation value.

b Calculated by (Model-Obs.)/Obs.

c Obtained from best-fitted curves. The method of Nakazawa et al. (1997) is used for fitting.

d Calculated by Model/Obs.

The stations in the tropics and southern low latitudes, such as Ascension Island, UK (ASC, in Fig. 4) and Mahe Island, Seychelles (SEY), show relatively small seasonal variation, but are characterized by two peaks in spring and autumn, with one large seasonal minimum between July and August. Our model results capture the patterns well and suggest that biomass burning in the northern and southern subtropics contribute to peak $\mathrm{H}_{2}$ mixing ratios in the spring and autumn, respectively. The active region of biomass burning near the equator alternates between the hemispheres in connection with the timing of the dry and wet seasons. The timing of the seasonal minimum is associated with the enhanced inflow of air from the Northern Hemisphere with the low $\mathrm{H}_{2}$ mixing ratio being amplified by strong soil uptake in the tropics.

The occurrences of maximum and minimum tropospheric $\mathrm{H}_{2}$ mixing ratios are quite different between the northern and the Southern Hemispheres (see Fig. 4). Around $30^{\circ}$ N, many stations show seasonal maxima between June and July. The seasonal minima appear during the period from October to December. The seasonal variation in this region is a result 


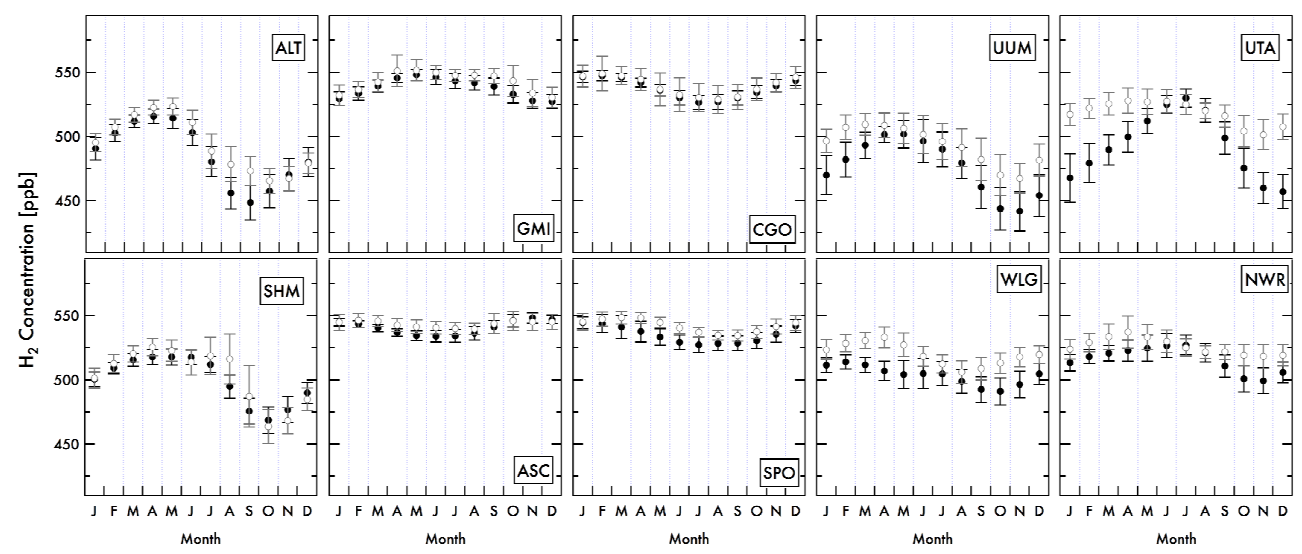

Fig. 4. Monthly mean $\mathrm{H}_{2}$ mixing ratios at the 10 selected observation sites. Abbreviations for each site are expressed in Table 1. Closed and open circles are the observed and calculated values, respectively. Error bars represent the standard deviations of the multi-year average during the period 1997-2005, which arise from both the day-to-day variation and inter-annual variation of the mixing ratio.
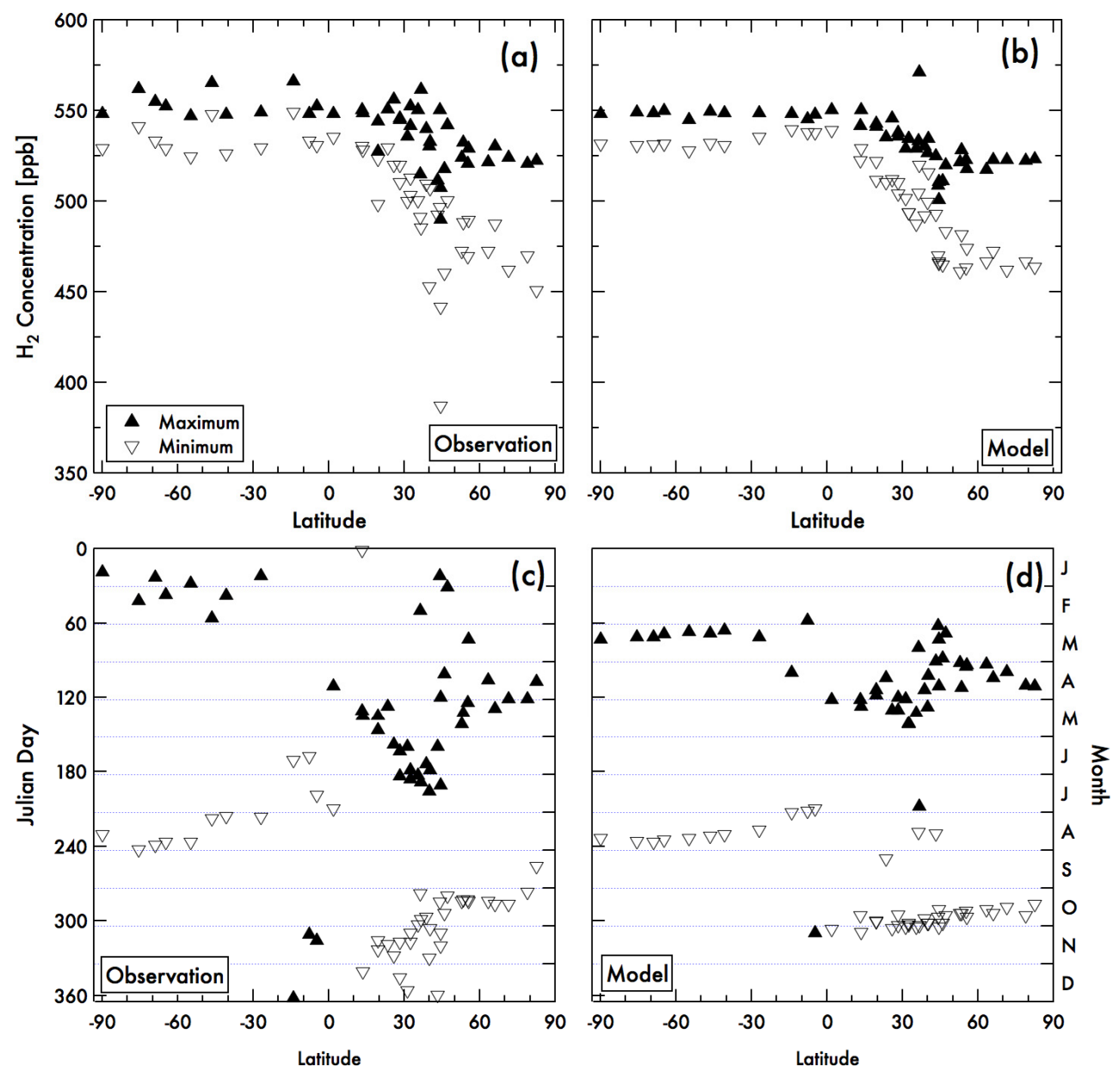

Fig. 5. Latitudinal distribution of the seasonal maximum (closed triangle) and minimum (open triangle) for $\mathrm{H}_{2}$ mixing ratio (upper panel, a, b) and for the occurrence date (lower panel, c, d). The values obtained from the observations are shown in panels (a) and (c) and from the model simulation $(\mathbf{b}, \mathbf{d})$. 

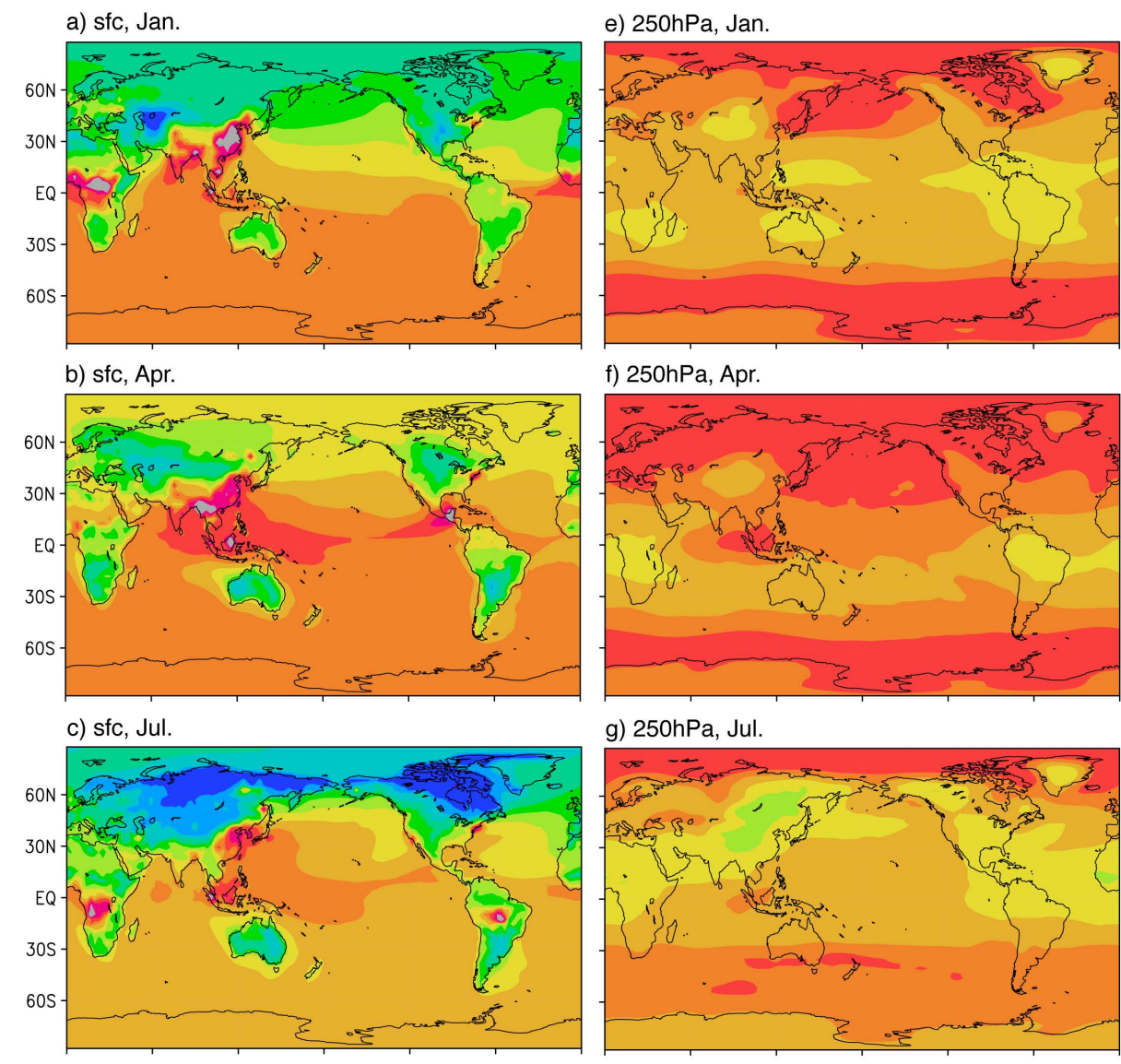

g) $250 \mathrm{hPa}$, Jul.
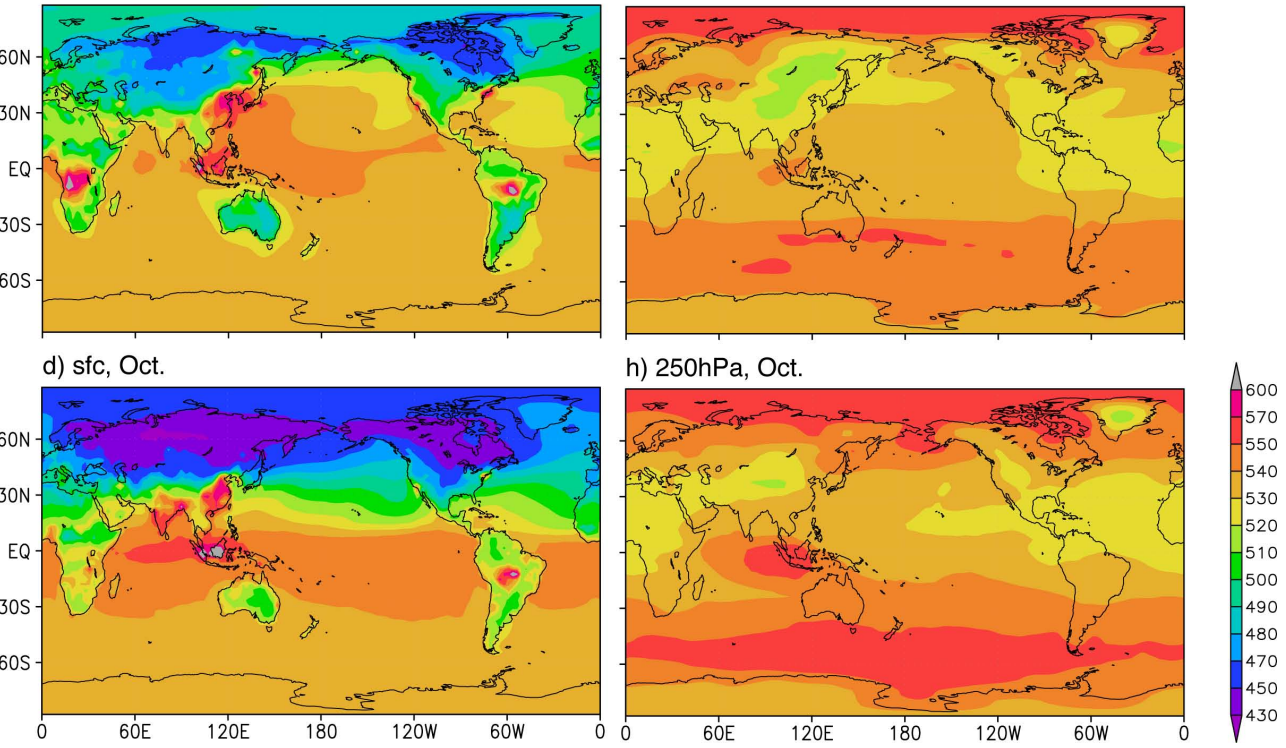

Fig. 6. Distribution of $\mathrm{H}_{2}$ mixing ratio (ppb) calculated at the surface (left panel) and $250 \mathrm{hPa}$ (right panel) for January (a, e), April (b, f), July $(\mathbf{c}, \mathbf{g})$, October $(\mathbf{d}, \mathbf{h})$. The values are averaged over the period of 1997-2005.

of a complicated combination of source/sink changes related to net chemical production in the atmosphere, oceanic emission, biomass burning, and soil uptake. Variations in the large-scale transport also contribute to the observed variation in $\mathrm{H}_{2}$. In general, the model reproduces the maximum and minimum values at many stations well, but causes both the maximum and minimum to occur one to two months earlier. For the inland sites near arid regions, such as Wendover, United States (UTA, in Fig. 4), Ulaan Uul, Mongolia (UUM, in Fig. 4), and Sary Taukum, Kazakhstan (KZD), large discrepancies between the model and observations are seen. The model results at these stations overestimate the magnitude of the seasonal minimum from the end of the autumn to the be- ginning of the spring. A possible cause of this could be due to a strong local uptake. In this study, the simulated deposition velocity shows a large variability in the semi-arid regions, because of the high soil diffusivity and limited biological activity due to water stress. In order to identify model variables that might influence the seasonal minimum in the winter season, we have conducted a series of sensitivity experiments in which we (1) decrease the soil moisture by $0.05 \mathrm{~m}^{3} \mathrm{~m}^{-3}$, (2) decrease the inactive soil layer from 0.7 to $0.3 \mathrm{~cm}$, and (3) change the frozen to non-frozen water ratio by increasing the non-frozen part by $30 \%$ around the model grid near UTA. Although these experiments do produce noticeably changes in the seasonal variation of the deposition velocity, the model 
fails to capture the observed sharp winter decrease in $\mathrm{H}_{2}$ at UTA. To resolve this issue, it may be necessary to increase the model resolution and improve the boundary layer mixing parameterization.

For regions north of $45^{\circ} \mathrm{N}$, the seasonal maximum appears in the late spring and the minimum at the beginning of the autumn at every station. The amplitude of the seasonal cycle increases poleward, reaching about $70 \mathrm{ppb}$ at Alert, Canada (ALT, in Fig. 4). This latitudinal change in the amplitude is related to the poleward decrease in the value of the seasonal minimum. The model results agree well with the observation in the timing of the occurrence of the seasonal maximum/minimum, as well as in the maximum value, but slightly underestimate the seasonal minimum. The latter problem may be caused by the way the physical property of the uppermost soil is represented in the model. For example, there is still a great deal of uncertainty associated with the air ratio at the soil surface, which is influenced by the melting of frozen soil in the summer. Furthermore, it is conceivable that the biologically inactive layer is thinner in high-latitude regions where the soil temperature remains relatively low even in the summer. At stations along the Pacific Rim, such as Shemya Island, United States (SHM, in Fig. 4) and Cold Bay, United States (CBA), we see large day-to-day fluctuations as $\mathrm{H}_{2}$ decreases from summer to autumn. These short-term fluctuations are caused by the synoptic variation in the transport of maritime and continental air masses with different $\mathrm{H}_{2}$ concentrations, the former influenced by the enhanced summer ocean emission of $\mathrm{H}_{2}$, and the latter by the strong soil uptake on the continent.

\subsubsection{Global distribution, budget and trend of $\mathrm{H}_{2}$}

The global distributions of simulated $\mathrm{H}_{2}$ mixing ratio at the surface and $250 \mathrm{hPa}$ in January, April, July, and October are shown in Fig. 6. Zonal averages of $\mathrm{H}_{2}$ distribution for the same months are shown in Fig. 7. The horizontal and vertical distributions of $\mathrm{H}_{2}$ mixing ratio are relatively uniform south of $45^{\circ} \mathrm{S}$, due mostly to the absence of strong surface sources and sinks. At Southern Hemisphere mid latitudes, the $\mathrm{H}_{2}$ mixing ratio in the free troposphere shows a zonal average of 530-540 ppb year-round. The mixing ratio near the ocean surface during the austral summer at this latitudinal band is $5-10 \mathrm{ppb}$ higher than in the upper troposphere, due mainly to the presence of oceanic sources. In contrast, the mixing ratio over the land surface shows values $10-30 \mathrm{ppb}$ lower than those in the free troposphere due to soil uptake. In the tropical region, oceanic emission and the net chemical production of $\mathrm{H}_{2}$ are relatively high throughout the year. In addition, biomass burning emits large amounts of $\mathrm{H}_{2}$, especially during the boreal spring and autumn, at least partially offsetting the large soil uptake.

The tropics and subtropics are regions where emissions of biogenic NMVOCs are strong and cumulus convection is active. This results in a strong vertical transport to the upper
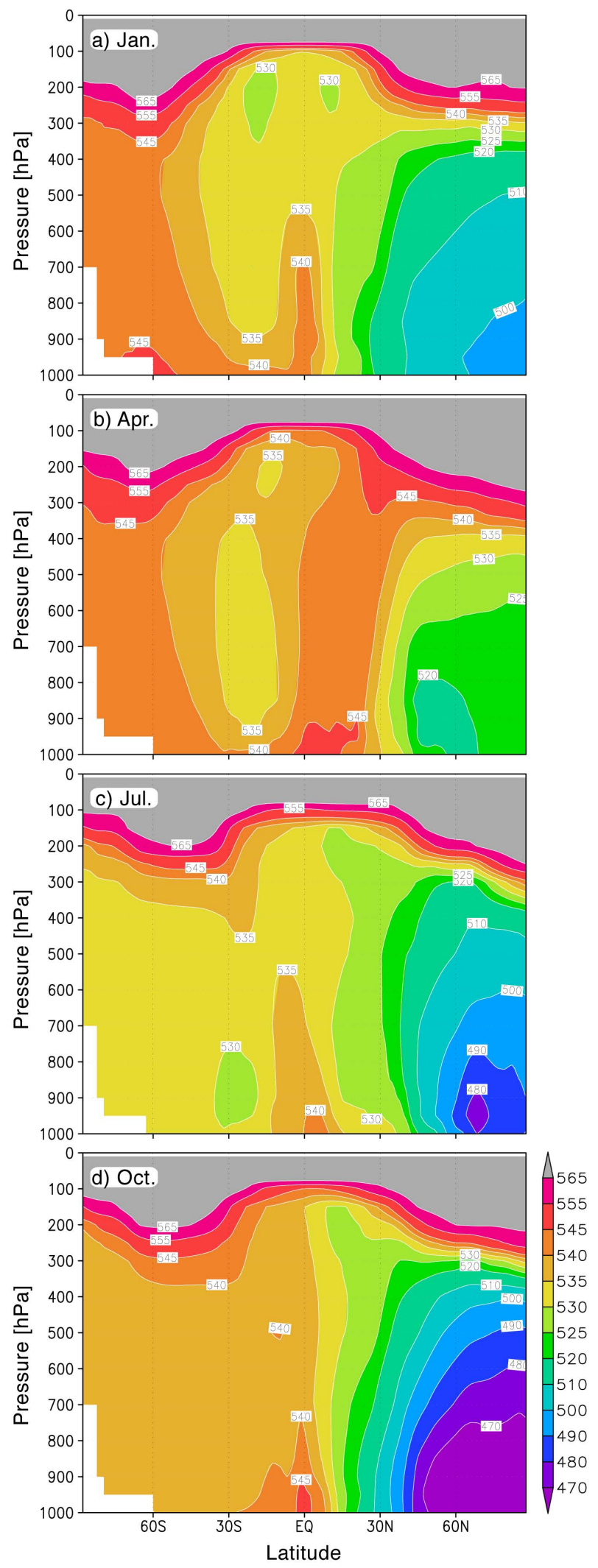

Fig. 7. Latitude-pressure cross-section of zonally averaged $\mathrm{H}_{2}$ mixing ratio (ppb) calculated for January (a), April (b), July (c), October (d). The values are averaged over the period 1997-2005. 
troposphere of NMVOCs and $\mathrm{NO}_{\mathrm{x}}$ from both the biogenic and pyrogenic sources at the surface. Enhanced chemical reactions result in a higher production of $\mathrm{H}_{2}$ at the $200-300 \mathrm{hPa}$ levels, compared with the situation in the lower free troposphere. However, vertical transport of the low- $\mathrm{H}_{2}$ air mass affected by soil uptake results in a region of relatively low $\mathrm{H}_{2}$ mixing ratio in the uppermost troposphere of the subtropics, mainly over the continents.

The Northern Hemisphere shows large seasonally varying vertical gradients in $\mathrm{H}_{2}$, with the maximum occurring in boreal spring and autumn, respectively. The lowest mixing ratio is seen near the surface of the northern high latitudes, with low mixing ratio areas spreading to the upper troposphere and lower latitudes. The contrast in the mixing ratio between land and ocean is large at northern mid- and high- latitudes. Anthropogenic emissions are strong in areas with large populations, such as North America, Europe, and China, resulting in high $\mathrm{H}_{2}$ mixing ratios, especially over China and India. In the summer (July, Fig. 6c), we see an area of high $\mathrm{H}_{2}$ mixing ratio over East Asia and Southeast Asia spreading to the western Pacific and further east along the subtropical Pacific, indicating an enhanced transport of oceanic air mass associated with the Asian monsoon.

The global $\mathrm{H}_{2}$ budget obtained by our model is summarized in Table 2, along with the results published in previous studies. The annual global averages of the simulated chemical sources and sinks for the period 1997 to 2005 are in the range of $38-39 \mathrm{Tg} \mathrm{yr}^{-1}$ and $17-18 \mathrm{Tg} \mathrm{yr}^{-1}$, with respective average values of $38.7 \pm 0.3 \mathrm{Tg} \mathrm{yr}^{-1}$ and $17.6 \pm 0.2 \mathrm{Tg} \mathrm{yr}^{-1}$. The annual total flux of soil uptake has a range of 57$60 \mathrm{Tg} \mathrm{yr}^{-1}$, with an average value of $58.7 \pm 0.9 \mathrm{Tg} \mathrm{yr}^{-1}$. These values correspond relatively well to values obtained by other forward integrating models (Hauglestain and Ehhalt, 2002; Sanderson et al., 2003; Price et al., 2007). However, Rhee et al. (2006) and Xiao et al. (2007) reported a larger estimate of the soil uptake flux ( 88 and $85 \mathrm{Tg} \mathrm{yr}^{-1}$, respectively) and chemical production (64 and $77 \mathrm{Tg} \mathrm{yr}^{-1}$, respectively). These larger production values resulted from the assumption of larger yields from the oxidation of NMVOCs. Ehhalt and Rohrer (2009) pointed out that the estimate of the soil uptake has a large uncertainty, and advocated a value of $60+30 /-20 \mathrm{Tg} \mathrm{yr}^{-1}$, which is close to our results. The estimate by Rhee et al. (2006) was based on a simplified calculation involving the seasonal variation of the concentration and isotope ratio of $\mathrm{H}_{2}$ in the free northern mid-latitude troposphere. They assumed that the Northern Hemisphere troposphere is well mixed and that the influence of the soil uptake and net chemical production is distributed uniformly in the vertical. However, as noted above, the footprint of the soil uptake in the upper troposphere is mediated by vertical convective transport in the tropics and subtropics, resulting in temporal and spatial heterogeneity in $\mathrm{H}_{2}$ concentration. Furthermore, the global simulation of $\mathrm{H}_{2}$ isotopes by Price et al. (2007) showed that the ground observations of $\delta D$ could be explained by a smaller $\mathrm{H}_{2}$ soil uptake than that estimated

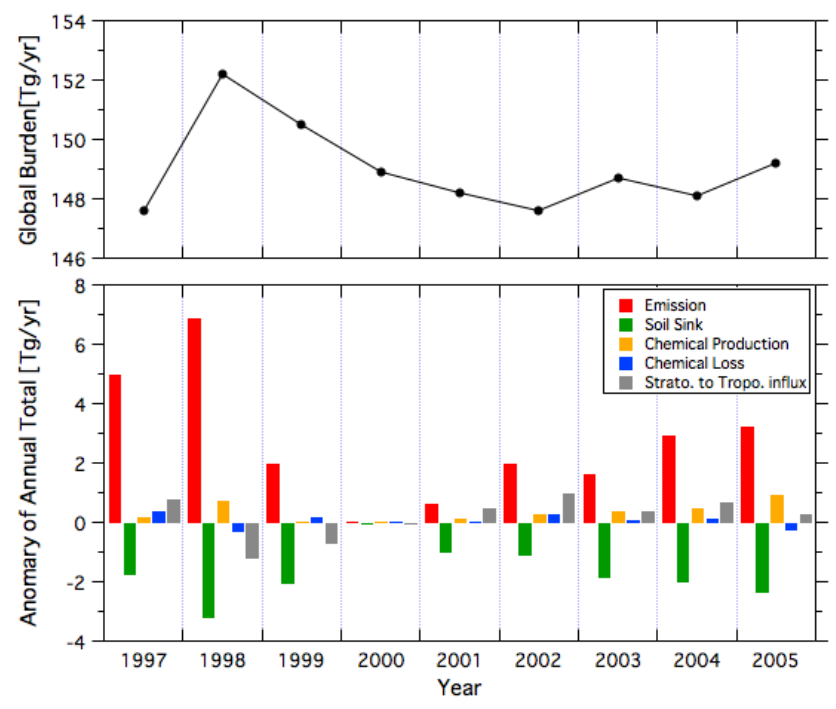

Fig. 8. Global annual averages of the sources and sinks of $\mathrm{H}_{2}$ (lower panel) and global burden of $\mathrm{H}_{2}$ (upper panel) during the period 1997-2005. Four budget terms are expressed as anomaly from 2000 , respectively, and the total sum of all the terms in 2000 is $-1.9 \mathrm{Tg} \mathrm{yr}^{-1}$.

by Rhee et al. (2006). Recent study of $\mathrm{H}_{2}$ isotope longterm ground measurements by Batenburg et al. (2011) also suggested that the contribution of soil uptake from Rhee et al. (2006) was most likely overestimate at Northern Hemisphere low latitudes. Xiao et al. (2007), on the other hand, used an inversion method with a 2-D multi-box model employing relatively few observations to constrain their results. One of the problems with this approach is that the seasonal variation of $\mathrm{H}_{2}$ near the surface is quite different over ocean and land, causing the 2-D inversion to be sensitive to the station location. When many observation sites near the continent are used, the influence of soil uptake may be overestimated. In our model, the soil uptake is calculated online and agrees with the uptake value endorsed by Ehhalt and Rohrer (2009). Furthermore, NMVOCs are calculated online for each time step, and their emissions are optimized to reproduce the observed $\mathrm{CO}$ and NMVOCs concentrations.

Novelli et al. (1999) showed that tropospheric $\mathrm{H}_{2}$ does not display a clear increasing or decreasing trend after 1995. Globally averaged source/sink $\mathrm{H}_{2}$ anomalies and the corresponding tropospheric burden are shown in Fig. 8. Superimposed on the gradual total emission increase, due mainly to the growing anthropogenic emissions, there is a noticeable inter-annual variability caused by emissions from large scale biomass burning. Especially the $\mathrm{H}_{2}$ emission from the Indonesian fires during 1997-1998, and from the forest fires in Siberia in 1998 are significant. In contrast, in 2000 there is very little biomass burning. We also see inter-annual variability in the soil uptake flux of $\mathrm{H}_{2}$, offsetting the emissions. The net total emission from the surface, along with the chemical production, of $\mathrm{H}_{2}$ is reflected in the tropospheric burden 
Table 2. Global tropospheric sources and sinks of $\mathrm{H}_{2}\left(\mathrm{TgH}_{2} \mathrm{yr}^{-1}\right)$.

\begin{tabular}{|c|c|c|c|c|c|c|c|c|c|}
\hline & & $\begin{array}{l}\text { Novelli et al. } \\
\text { (1999) }\end{array}$ & $\begin{array}{l}\text { Hauglustain and Ehhalt } \\
\qquad(2002)\end{array}$ & $\begin{array}{l}\text { Sanderson et al. } \\
\qquad(2003)\end{array}$ & $\begin{array}{l}\text { Rhee et al. } \\
\text { (2006) }\end{array}$ & $\begin{array}{l}\text { Price et al. } \\
\quad(2007)\end{array}$ & $\begin{array}{l}\text { Xiao et al. } \\
\text { (2007) }\end{array}$ & $\begin{array}{c}\text { Ehhalt et al. } \\
\text { (2009) }\end{array}$ & This Study $^{\mathrm{a}}$ \\
\hline \multirow{2}{*}{$\begin{array}{l}\text { Anthropogenic } \\
(\mathrm{FF}+\mathrm{BF})\end{array}$} & & $15 \pm 10$ & 16 & 20.0 & $15 \pm 6$ & 23.7 & $15 \pm 10$ & $11 \pm 4$ & $15.1-15.4$ \\
\hline & $\begin{array}{l}\text { Fossil fuel, } \\
\text { industrial (FF) } \\
\text { Biofuel (BF) }\end{array}$ & & & & & $\begin{array}{l}(18.3) \\
(4.4)\end{array}$ & & & \\
\hline Biomass Burning & & $16 \pm 5$ & 13 & 20.0 & $16 \pm 3$ & 10.1 & $13 \pm 3$ & $15 \pm 6$ & $8-15$ \\
\hline \multirow{2}{*}{$\begin{array}{l}\text { Biogenic N2 } \\
\text { fixation }\end{array}$} & Ocean & $3 \pm 2$ & 5 & 4.0 & $6 \pm 5$ & 6.0 & & $6 \pm 3$ & 6 \\
\hline & Land & $3 \pm 1$ & 5 & 4.0 & $6 \pm 5$ & & & $3 \pm 2$ & 3 \\
\hline $\begin{array}{l}\text { Total surface } \\
\text { source }\end{array}$ & & 37 & 39 & 48 & 43 & 39.8 & 28 & 35 & $30-37$ \\
\hline $\begin{array}{l}\text { Total } \\
\text { chemical reaction } \\
\text { source }\end{array}$ & & 40 & 31 & 30.2 & $64 \pm 12$ & 34.3 & $77 \pm 10$ & $41 \pm 11$ & $38-39$ \\
\hline $\begin{array}{l}\text { Strato. to Tropo. } \\
\text { influx }\end{array}$ & & & & & & & & & $4-6$ \\
\hline Total source & & $77 \pm 16$ & 70 & 78.2 & $107 \pm 15$ & 73 & $105 \pm 10$ & $76 \pm 14$ & $73-80$ \\
\hline Soil uptake & & $56 \pm 41$ & 55 & 58.3 & $88 \pm 11$ & $55 \pm 8.3$ & $85 \pm 5$ & $60_{-20}^{+30}$ & $57-60 \pm 12^{b}$ \\
\hline $\begin{array}{l}\text { Total chemical } \\
\text { reaction sink }\end{array}$ & & $19 \pm 5$ & 15 & 17.1 & $19 \pm 3$ & 18 & $18 \pm 3$ & $19 \pm 5$ & 17-18 \\
\hline Total Sink & & $75 \pm 41$ & 70 & 75.4 & $107 \pm 11$ & 73 & $107 \pm 11$ & $79_{-20}^{+30}$ & $75-78$ \\
\hline Burden & & $155 \pm 10$ & 136 & 172 & 150 & 141 & $149 \pm 23$ & $155 \pm 10$ & $148-153$ \\
\hline $\begin{array}{l}\text { Tropospheric } \\
\text { lifetime }\end{array}$ & & 2.1 & 1.9 & 2.3 & 1.4 & 1.9 & 1.4 & 2 & $1.9-2.0$ \\
\hline
\end{tabular}

a The range given represents the range of annual average for model simulation time period (1997-2005)

$\mathrm{b}$ The uncertainty estimated in this study (see Chapter 3.3)

of $\mathrm{H}_{2}$, which shows a slight increasing (but not significant) trend from 2002 to 2005. The biomass burning in 1998 caused a temporary spike in the tropospheric burden, but recovered in about two years. The observed $\mathrm{H}_{2}$ mixing ratio also shows another peak during 1997-1998 (Fig. 3). The summertime increase in 1998 was observed at nearly all stations and the model is found to reproduce it relatively well. Both the chemical production and loss show an increasing trend. However, the amounts of change are very small compared with changes in surface $\mathrm{H}_{2}$ emissions. In this study, net annual influxes of $\mathrm{H}_{2}$ from the stratosphere to the troposphere are calculated to vary from 4 to $6 \mathrm{Tg} \mathrm{yr}^{-1}$ indicating small inter-annual variation.

The soil uptake not only responds to an increase in atmospheric concentration, but also to changes in soil temperature and moisture. The long-term variations in the total and average values of simulated soil uptake flux, deposition velocity, and soil moisture in the four latitude bands are shown in Fig. 9. They are obtained by applying the curve fitting method of Nakazawa et al. (1997). In the figure, both the soil uptake flux and the deposition velocity in the tropics show a noticeable inter-annual variation compared with other latitudinal bands. In 2000, we see a decrease in the deposition velocity correlated with an increase in the soil moisture caused by an increase in precipitation over land. By examining the normalized Southern Oscillation index (SOI) obtained by
Ropelewski and Halpert (1987) (also shown in Fig. 9), the increase in soil moisture in 2000 is linked to an increase in precipitation around Indonesia caused by a La Nina event. Although an increase in precipitation on land in a tropical region decreases the soil uptake of $\mathrm{H}_{2}$, it actually reduces the frequency of biomass burning in the same area. This balance between the reduced emission and reduced soil uptake produces very little change in the atmospheric $\mathrm{H}_{2}$ mixing ratio, as was the case in the tropics in 2000.

\subsection{Possible uncertainty in the soil uptake flux}

In the soil diffusion model used in this study, the factors that produce uncertainties in the soil estimate are the soil diffusion coefficient, the degree of biological activity, and the inactive layer thickness. The diffusivity and the biological activity are determined by the air ratio in the soil, soil moisture, and soil temperature. Prediction errors of these variables are expected to affect the deposition velocity of $\mathrm{H}_{2}$. In general, the good agreement between our model result and the observations gives indirect support to the ability of our model to reproduce relatively well the soil moisture and temperature. Furthermore, inter-annual variations in the soil variables do not appear to produce large variations in the global soil uptake, thus having minimal impact on the budget for tropospheric $\mathrm{H}_{2}$. The factor that produces greater uncertainty is 

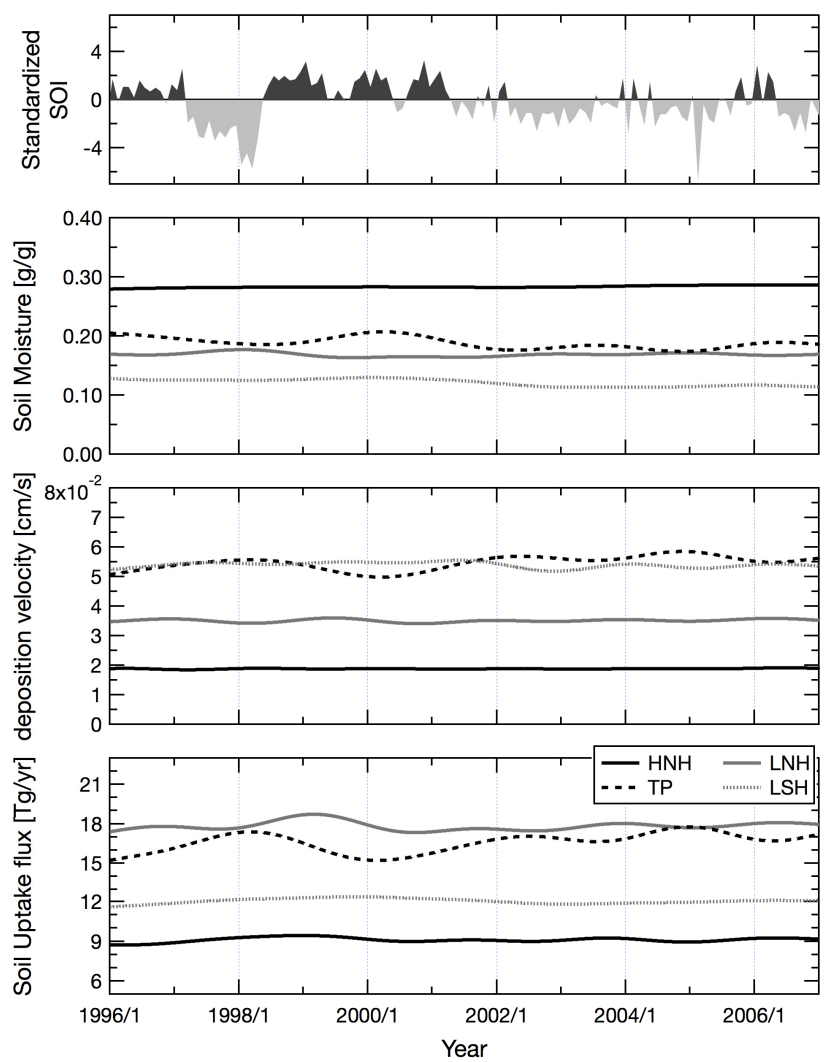

Fig. 9. Long-term trends of soil uptake flux, deposition velocity, and soil moisture for the four latitudinal bands. The latitudinal ranges of HNH, LNH, TP, and LSH are the same as for Fig. 2. The normarized Southern Oscillation Index (SOI) from Ropellewski and Halpert [1987] is also shown.

associated with the specification of soil properties, such as the ratio of soil surface area to aerial volume. The physical structure of the soil within the first several centimeters from the surface changes significantly, thus requiring a better and more detailed distribution of soil variables, with greater vertical resolution in the top layer. In this study, a correction of $0.22 \mathrm{~m}^{3} \mathrm{~m}^{-3}$ is uniformly applied to the air ratio since the air ratio in the uppermost layer is non-uniformly distributed. However, this correction is very crude and is not sufficient to capture the sharp change in the air ratio near the surface.

The reproducibility of the station observations near semiarid regions in central Asia and North America is not good in this study. The seasonal $\mathrm{H}_{2}$ minimum cannot be reproduced well, probably due to an underestimation of the deposition velocity around the observation stations. Semi-arid regions have a large potential for $\mathrm{H}_{2}$ uptake, but the uptake is prevented for the soil dryness. That is, the soil uptake of $\mathrm{H}_{2}$ in semi-arid regions is highly sensitive to change in the vertical distribution of soil moisture. The ratio of frozen to unfrozen water also may have a large impact on the soil uptake at cold semi-arid region.

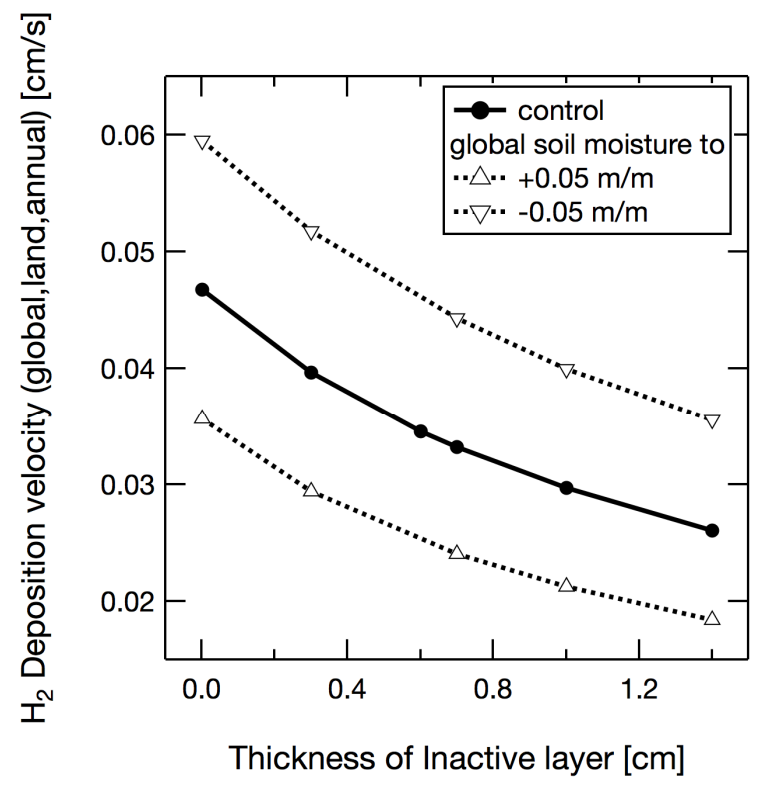

Fig. 10. The sensitivity experiments on the change in the global averaged $\mathrm{H}_{2}$ deposition velocity on land as a function of the thickness of the inactive layer.

Furthermore, a better representation of arable land is important in improving the estimation of global $\mathrm{H}_{2}$ uptake by the soil. Although we do not carry out model verification with regards to the $\mathrm{H}_{2}$ uptake by arable land, we realize that seasonal changes in the surface conditions and in the vertical soil properties are significant and will likely have a large impact on the soil uptake estimate. Large variations in soil properties and the inactive layer thickness caused by strong sunlight can take place over a short time period.

We have a very poor knowledge of the global distribution of the inactive layer thickness. The formation of the inactive layer is mainly due to irreversible destruction of enzymes or bacteria near the surface. Thus, the temporal change in the inactive layer thickness is influenced not only by physical stress, such as extreme heating and drying, but also by the recovery/redistribution rate of microbes and enzymes. Figure 10 shows the sensitivity of the annually averaged deposition velocity on land to the thickness of the inactive layer $\delta$ for three different values of global soil moisture (control $\pm 0.05 \mathrm{~m} \mathrm{~m}^{-1}$ ). If we apply $\pm 0.05 \mathrm{~m} \mathrm{~m}^{-1}$ change to the global soil moisture (control), the deposition velocity shifts up or down (relative to the control) by about $0.01 \mathrm{~cm} \mathrm{~s}^{-1}$. For changes in the inactive layer thickness, we see a near $50 \%$ difference in the deposition velocity between $\delta=0$ and $\delta=1.0 \mathrm{~cm}$. This is equivalent to a $25-30 \mathrm{Tg} \mathrm{yr}^{-1}$ difference in the global soil uptake, which is not negligible, considering the size of the global $\mathrm{H}_{2}$ budget.

In this study, we adopted $\delta=0.7 \mathrm{~cm}$ to optimize the model agreement with the observation. However, this is not a unique solution. We can have different combinations of $\delta$ 
and the air ratio correction (free parameters) to optimize the model-observation agreement. For example, we can employ a combination of $\delta=0.3 \mathrm{~cm}$ and the air ratio correction of $0.19 \mathrm{~m}^{3} \mathrm{~m}^{-3}$ or $\delta=1.0 \mathrm{~cm}$ and $0.24 \mathrm{~m}^{3} \mathrm{~m}^{-3}$, to obtain similar results. It is interesting to note that the impact of these modifications on the seasonal variation at the observational sites is minimal.

With the assumption that $\delta$ has a range of 0.3 to $1.4 \mathrm{~cm}$ (which is equivalent to an uncertainty range of $\pm 0.03 \mathrm{~m}^{3} \mathrm{~m}^{-3}$ for the globally-averaged soil moisture), we obtain an uncertainty of $\pm 20 \%$ for the estimated deposition velocity over the land which gives a value of $\pm 12 \mathrm{Tg} \mathrm{yr}^{-1}$ uncertainty for the global soil uptake estimate. Although the assumed range of $\delta$ is consistent with those estimated by other investigators (Yonemura et al., 2000b; Shmitt et al., 2009), we need much more observations to obtain a more realistic idea of the horizontal distribution and the seasonal variation of the inactive layer.

\section{Conclusions}

We have conducted a global simulation of tropospheric $\mathrm{H}_{2}$ mixing ratios and evaluated its uptake by the soil using the global chemical transport model, CHASER. The soil diffusion model, which has an inactive and active layer of biological consumption, is incorporated into the dry deposition scheme. The variation in soil diffusivity and biological activity in the soil are calculated as a function of soil temperature and moisture, which are calculated as prognostic variables in the land process module of the model. The model results for the regional distribution and seasonal variation of the $\mathrm{H}_{2}$ deposition velocity agree relatively well with the observed values obtained by other investigators.

A large seasonal variation in the deposition velocity corresponding to changes in soil temperature and snowfall is seen at the Northern Hemisphere high latitudes. In the midlatitudes of both hemispheres and the tropics, we identified two types of region where (1) biological uptake is active because of the warm climate, but the wet environment counters the diffusion into the soil, and (2) the biological activity becomes weaker due to high temperature and dryness, but the dry climate makes the transportation in the soil more efficient. The strength of the soil uptake is closely related to the water and heat budget in each region.

The tropospheric $\mathrm{H}_{2}$ mixing ratio calculated by the model reproduces the mixing ratio observed at the NOAA stations relatively well. The seasonal variation of the mixing ratio in the Southern Hemisphere is mainly due to the net chemical production in the austral summer and the inflow of air with relatively low $\mathrm{H}_{2}$ from the north following the north-south transport during the austral winter. The vertical and horizontal gradients are small in the Southern Hemisphere. In the tropics, both the net chemical production and the soil uptake are high throughout the year and the impact of biomass burning is superimposed on this during January and September. Furthermore, in the tropical region, active cumulus convection transports air mass influenced by both the soil uptake and biomass burning near the surface to the upper troposphere. Biogenic NMVOCs are also transported to high altitudes over the Amazon and Africa, allowing for more production of $\mathrm{H}_{2}$ by chemical reactions. Seasonal variation in soil uptake is a dominant contributor to the $\mathrm{H}_{2}$ variation in the Northern Hemisphere. During the boreal summer, a strong uptake by the soil surface produces a large vertical gradient, land-sea gradient, and latitudinal gradient in the $\mathrm{H}_{2}$ mixing ratio.

For our simulation period of 1997 to 2005 , the average tropospheric burden and lifetime are found to be $150 \mathrm{Tg}$ and $2.0 \mathrm{yr}$, respectively. The annual total amount of chemical production, chemical loss, and soil uptake are 39, 18 and $59 \mathrm{Tg} \mathrm{yr}^{-1}$, respectively. The budget calculated from our simulation agrees with the lower end of the estimated values obtained by previous forward integrating model studies.

Our model is able to reproduce the overall inter-annual variation observed during the period 1997-2005. Large $\mathrm{H}_{2}$ peaks caused by large biomass burning in Indonesia and Siberia were observed in 1997 and 1998, respectively, at nearly all stations. Our model is able to successfully reproduce these peaks.

The tropospheric $\mathrm{H}_{2}$ concentration shows no significant long-term trend. Our model result shows that the soil uptake flux changes in the direction that offsets the increase in $\mathrm{H}_{2}$ emission to the atmosphere. The simulated $\mathrm{H}_{2}$ deposition velocity shows a small trend and inter-annual variation. We conclude that the recent decadal climate change has had very little impact on the atmospheric $\mathrm{H}_{2}$ concentration.

The global soil uptake flux of $\mathrm{H}_{2}$ obtained by our model succeeds in reproducing the tropospheric $\mathrm{H}_{2}$ mixing ratio and its seasonal variation observed at many of the stations distributed throughout the world. However, in regions where there is a strong $\mathrm{H}_{2}$ uptake, uncertainties in both uptake flux and atmospheric mixing ratio are still large. In order to improve these estimates of the soil uptake flux and to reproduce/predict the present/future mixing ratio of $\mathrm{H}_{2}$ in the atmosphere, it is necessary to gain the knowledge of the vertical structure of physical soil properties and the response behavior of the microbial activity in the shallow top layer of the soil. In particular, a significant improvement in the understanding and reproducibility of soil properties of the arable land and the semi-arid region, where soil temperature and moisture can change drastically over a short time period, is required.

Acknowledgements. The authors thank the members for the development of the CCSR/NIES/FRCGC MIROC-AGCM, T. Ohara and J. Kurokawa at National Institute for Environmental Studies (NIES) for providing the detailed emission inventories of REAS, and the anonymous reviewers for valuable comments. We also acknowledge Paul Novelli for providing $\mathrm{H}_{2}$ data of NOAA/ESRL 
observation network. Computations were made on a HITACHI HA8000 Cluster System (T2K Open Super Computer) at the Information Technology Center, University of Tokyo.

Edited by: T. Röckmann

\section{References}

Andreae, M. O. and Merlet, P.: Emission of trace gases and aerosols from biomass burning, Global Biogeochem. Cy., 15, 955-966, 2001.

Atkinson, R., Baulch, D. L., Cox, R. A., Crowley, J. N., Hampson, R. F., Hynes, R. G., Jenkin, M. E., Rossi, M. J., and Troe, J.: Evaluated kinetic and photochemical data for atmospheric chemistry: Volume I - gas phase reactions of Ox, HOx, NOx and $\mathrm{SO}_{\mathrm{x}}$ species, Atmos. Chem. Phys., 4, 1461-1738, doi:10.5194/acp-41461-2004, 2004.

Batenburg, A. M., Walter, S., Pieterse, G., Levin, I., Schmidt, M., Jordan, A., Hammer, S., Yver, C., and Röckmann, T.: Temporal and spatial variability of the stable isotopic composition of atmospheric molecular hydrogen: observations at six EUROHYDROS stations, Atmos. Chem. Phys. Discuss., 11, 10087-10120, doi:10.5194/acpd-11-10087-2011, 2011.

Conrad, R.: Soil microorganisms as controllers of atmospheric trace gases $\left(\mathrm{H}_{2}, \mathrm{CO}, \mathrm{CH}_{4}, \mathrm{OCS}, \mathrm{N}_{2} \mathrm{O}\right.$, and $\left.\mathrm{NO}\right)$, Microbiol. Rev., 60 , 609-640, 1996.

Conrad, R. and Seiler, W.: Influence of temperature, moisture, and organic carbon on the flux of $\mathrm{H}_{2}$ and $\mathrm{CO}$ between soil and atmosphere: field studies in subtropical regions, J. Geophys. Res., 90, 5699-5709, 1985.

Conrad, R., Weber, M., and Seiler, W.: Kinetics and electron transport of soil hydrogenases catalyzing the oxidation of atmospheric hydrogen, Soil Biol. Biochem., 15(2), 167-173, doi:10.1016/0038-0717(83)90098-6, 1983.

Constant, P., Chowdhury, S. P., Pratscher, J., and Conrad, R., Streptomycetes contributing to atmospheric molecular hydrogen soil uptake are widespread and encode a putative highaffinity [NiFe]-hydrogenase, Environ. Microbiol., 12: 821-829. doi:10.1111/j.1462-2920.2009.02130.x, 2010.

Ehhalt, D. H. and Rohrer, F.: The tropospheric cycle of $\mathrm{H}_{2}$ : a critical review, Tellus B, 61, 500-535, doi:10.1111/j.16000889.2009.00416.x, 2009.

Guenther, A., Hewitt, C. N., Erickson, D., Fall, R., Geron, C., Graedel, T., Harley, P., Klinger, L., Lerdau, M., Mckay, W. A., Pierce, T., Scholes, B., Steinbrecher, R., Raja, T., Taylor, J., and Zimmerman, P.: A global model of natural volatile organic compound emissions, J. Geophys. Res. 100, 8873-8892, 1995.

Hauglustaine, D. A. and Ehhalt, D. H.: A three-dimensional model of molecular hydrogen in the troposphere, J. Geophys. Res., 107, 4330, doi:10.1029/2001JD001156, 2002

Hirabayashi, Y., Kanae, S., Struthers, I., and Oki, T.: A 100-year (1901-2000) global retrospective estimation of the terrestrial water cycle: J. Geophys. Res., 110, D19101, doi:10.1029/2004JD005492, 2005.

K-1 Model Developers, K-1 coupled model (MIROC) description, edited by: Hasumi, H. and Emori, S., K-1 technical report. 34 pp., available at the Center for Climate System Research, University of Tokyo, Japan, http://www.ccsr.u-tokyo.ac.jp/ agcmadm/, 2004.
Koster, R. D., Dirmeyer, P. A., Guo, Z. C., Bonan, G., Chan, E., Cox, P., Gordon, C. T., Kanae, S., Kowalczyk, E., Lawrence, D., Liu, P., Lu, C. H., Malyshev, S., McAvaney, B., Mitchell, K., Mocko, D., Oki, T., Oleson, K., Pitman, A., Sud, Y. C., Taylor, C. M., Verseghy, D., Vasic, R., Xue, Y. K., and Yamada, T.: Regions of strong coupling between soil moisture and precipitation, Science, 305, 1138-1140, 2004.

Lallo, M., Aalto, T., Laurila, T., and Hatakka, J.: Seasonal variations in hydrogen deposition to boreal forest soil in southern Finland, Geophys. Res. Lett., 35, L04402, doi:10.1029/2007GL032357, 2008.

Millington, R. J. and Quirk, J. P.: Permeability of porous media, Nature 183, 387-388, 1959.

Miyazaki, K., Iwasaki, T., Shibata, K., Deushi, M., and Sekiyama, T.: The impact of changing meteorological variables to be assimilated into GCM on ozone simulation with MRI CTM, J. Meteorol. Soc. Jpn., 83, 909-918, 2005.

Müller, J.-F.: Geographical distribution and seasonal variation of surface emissions and deposition velocities of atmospheric trace gases, J. Geophys. Res., 97, 3787-3804, 1992.

van Noije, T. P. C., Eskes, H. J., Dentener, F. J., Stevenson, D. S., Ellingsen, K., Schultz, M. G., Wild, O., Amann, M., Atherton, C. S., Bergmann, D. J., Bey, I., Boersma, K. F., Butler, T., Cofala, J., Drevet, J., Fiore, A. M., Gauss, M., Hauglustaine, D. A., Horowitz, L. W., Isaksen, I. S. A., Krol, M. C., Lamarque, J.F., Lawrence, M. G., Martin, R. V., Montanaro, V., Müller, J.-F., Pitari, G., Prather, M. J., Pyle, J. A., Richter, A., Rodriguez, J. M., Savage, N. H., Strahan, S. E., Sudo, K., Szopa, S., and van Roozendael, M.: Multi-model ensemble simulations of tropospheric $\mathrm{NO}_{2}$ compared with GOME retrievals for the year 2000, Atmos. Chem. Phys., 6, 2943-2979, doi:10.5194/acp-6-29432006, 2006.

Novelli, P. C., Lang, P. M., Masarie, K. A., Hurst, D. F., Myers, R., and co-authors, Molecular hydrogen in the troposphere: global distribution and budget, J. Geophys. Res., 104, 30427-30444, 1999.

Ohara, T., Akimoto, H., Kurokawa, J., Horii, N., Yamaji, K., Yan, X., and Hayasaka, T.: An Asian emission inventory of anthropogenic emission sources for the period 1980-2020, Atmos. Chem. Phys., 7, 4419-4444, doi:10.5194/acp-7-4419-2007, 2007.

Olivier, J. G. J., Van Aardenne, J. A., Dentener, F., Ganzeveld, L., and Peters, J. A. H. W.: Recent trends in global greenhouse gas emissions: regional trends and spatial distribution of key sources, in: Non- $\mathrm{CO}_{2}$ Greenhouse Gases (NCGG-4), edited by: van Amstel, A., Millpress, Rotterdam, The Netherlands, 325-330, 2005.

Onogi, K., Tsutsui, J., Koide, H., Sakamoto, M., Kobayashi, S., Hatsushika, H., Matsumoto, T., Yamazaki, N., Kamahori, H., Takahashi, K., Kadokura, S., Kato, K., Oyama, R., Ose, T., Mannoji, N., and Taira, R.: The JRA-25 Reanalysis, J. Meteor. Soc. Jpn., 85, 369-432, 2007.

Pieterse, G., Krol, M. C., Batenburg, A. M., Steele, L. P., Krummel, P. B., Langenfelds, R. L., and Röckmann, T.: Global modelling of $\mathrm{H} 2$ mixing ratios and isotopic compositions with the TM5 model, Atmos. Chem. Phys. Discuss., 11, 5811-5866, doi:10.5194/acpd-11-5811-2011, 2011.

Prather, M. J.: An environmental experiment with H2?, Science 302, 581-582, 2003.

Price, H., Jaegle, L., Rice, A., Quay, P., Novelli, P. C., and 
Gammon, R.: Global budget of molecular hydrogen and its deuterium content: constraints from ground station, cruise, and aircraft observations, J. Geophys. Res., 112, D22108, doi:10.1029/2006JD008152, 2007.

Rhee, T. S., Brenninkmeijer, C. A. M., and Röckmann, T.: The overwhelming role of soils in the global atmospheric hydrogen cycle, Atmos. Chem. Phys. 6, 1611-1625, doi:10.5194/acp-61611-2006, 2006.

Ropelewski, C. F. and Halpert, M. S.: Global and regional scale precipitation patterns associated with the El Nino/Southern Oscillation, Mon. Weather Rev., 115, 1606-1626, 1987.

Sanderson, M. G., Collins, W. J., Derwent, R. G., and Johnson, C. E.: Simulation of global hydrogen levels using a Lagrangian three-dimensional model, J. Atmos. Chem. 46, 15-28, 2003.

Schmitt, M., Hanselmann, U., Wollschlager, U., Hammer, S., and Levin, I.: Investigation of parameters controlling the soil sink of atmospheric molecular hydrogen, Tellus B, 61, 416-423, 2008.

Schultz, M. G., Diehl, T., Brasseur, G. P., and Zittel, W.: Air pollution and climate-forcing impacts of a global hydrogen economy, Science, 302, 624-627, 2003.

Sekiguchi, M., and Nakajima, T.: A k-distribution-based radiation code and its computational optimization for an atmospheric general circulation model, J. Quant. Spectrosc. Radiat. Transfer, 109, 2779-2793, 2008.

Shindell, D., Faluvegi, G., Stevenson, D., Krol, M., Emmons, L., Lamarque, J.-F., Petron, G., Dentener, F., Ellingsen, K., Schultz, M., Wild, O., Amann, M., Atherton, C., Bergmann, D., Bey, I., Butler, T., Cofala, J., Collins, W., Derwent, R., Doherty, R., Drevet, J., Eskes, H., Fiore, A., Gauss, M., Hauglustaine, D., Horowitz, L., Isaksen, I., Lawrence, M., Montanaro, V., Muller, J.-F., Pitari, G., Prather, M., Pyle, J., Rast, S., Rodriguez, J., Sanderson, M., Savage, N., Strahan, S., Sudo, K., Szopa, S., Unger, N., van Noije, T., and Zeng, G.: Multimodel simulations of carbon monoxide: Comparison with observations and projected near-future changes, J. Geophys. Res., 111, D19306, doi:10.1029/2006JD007100, 2006.

Smith-Downey, N. V.: Soil uptake of molecular hydrogen and remote sensing of soil freeze and thaw, Ph.D. thesis, Calif. Inst. of Technol., Pasadena, Calif, 116 pp., $2006 a$.

Smith-Downey, N. V., Randerson, J. T., and Eiler, J. M.: Temperature and moisture dependence of soil $\mathrm{H}_{2}$ uptake measured in the laboratory, Geophys. Res. Lett., 33, L14813, doi:10.1029/2006GL026749, 2006b.

Smith-Downey, N. V., Randerson, J. T., and Eiler, J. M.: Molecular hydrogen uptake by soil in forest, desert and marsh ecosystems in California, J. Geophys. Res., 113, G03037, doi:10.1029/2008JG000701, 2008.

Sudo, K., Takahashi, M., Kurokawa, J., and Akimoto, H.: CHASER: A global chemical model of the troposphere: 1. Model description, J. Geophys. Res., 107(D17), 4339, doi:10.1029/2001JD001113, 2002a.
Sudo, K., Takahashi, M., and Akimoto H.: CHASER: A global chemical model of the troposphere: 2. Model results and evaluation, J. Geophys. Res., 107(D21), 4586, doi:10.1029/2001JD001114, 2002b.

Sudo, K., and Akimoto, H.: Global source attribution of tropospheric ozone: Long-range transport from various source regions, J. Geophys. Res., 112, D12302, doi:10.1029/2006JD007992, 2007.

Takata, K., Emori, S., and Watanabe, T.: Development of the Minimal Advanced Treatments of Surface Interaction and RunOff (MATSIRO), Global Planet. Change, 38, 209-222, 2003.

Tromp, T. K., Shia, R.-L., Allen, M., Eiler, J. M., and Yung, Y. L.: Potential environmental impact of a hydrogen economy on the stratosphere, Science, 300, 1740-1742, 2003.

Warwick, N. J., Bekki, S., Nisbet, E. G., and Pyle, J. A.: Impact of a hydrogen economy on the stratosphere and troposphere studied in a 2-D model, Geophys. Res. Lett., 31, L05107, doi:10.1029/2003GL019224, 2004.

Watanabe, S., Miura, H., Sekiguchi, M., Nagashima, T., Sudo, K., Emori, S., and Kawamiya, M.: Development of an atmospheric general circulation model for integrated Earth system modeling on the Earth simulator. J. Earth Simulator, 9, 28-35, 2008.

Van der Werf, G. R., Randerson, J. T., Giglio, L., Collatz, G. J., Kasibhatla, P. S., and Arellano Jr., A. F.: Interannual variability in global biomass burning emissions from 1997 to 2004, Atmos. Chem. Phys., 6, 3423-3441, doi:10.5194/acp-6-3423-2006, 2006.

Wesely, M. L.: Parameterization of surface resistances to gaseous dry deposition in regional-scale numerical models, Atmos. Environ., 23, 1293-1304, 1989.

Xiao, X., Prinn, R. G., Simmonds, P. G., Steele, L. P., Novelli, P. C., and co-authors: Optimal estimation of the soil uptake of molecular hydrogen from the Advanced Global Atmospheric Gases Experiments and other measurements. J. Geophys. Res. 112, D07303, doi:10.1029/2006JD007241, 2007.

Yonemura, S., Kawashima, S., and Tsuruta, H.: Continuous measurements of $\mathrm{CO}$ and $\mathrm{H}_{2}$ deposition velocities onto an andisol: uptake control by soil moisture, Tellus 51B, 688-700, 1999.

Yonemura, S., Yokozawa, M., Kawashima, S., and Tsuruta, H.: Model analysis of the influence of gas diffusivity in soil on $\mathrm{CO}$ and $\mathrm{H}_{2}$ uptake, Tellus 52B, 919-933, 2000a.

Yonemura, S., Kawashima, S., and Tsuruta, H.: Carbon monoxide, hydrogen, and methane uptake by soils in a temperate arable field and a forest, J. Geophys. Res., 105, 14347-14362, 2000 b. 